\title{
10
}

\section{The Development of Arandic Subsection Names in Time and Space}

\author{
Harold Koch
}

\section{Introduction}

This chapter builds on the findings of McConvell $(1985,1996)$ regarding the spread of subsection terms in north central Australia. ${ }^{1}$ It explores the timing and direction of the spread of section and subsection terms into the Arandic subgroup of languages in finer detail, and takes into consideration historical evidence from early sources such as Gillen's correspondence (Mulvaney et al. 1997). The chapter pays particular attention to issues of phonological change within the Arandic languages (Koch 1997b) and principles of adaptation of loan words between these languages and Warlpiri, as outlined in Koch (1997a, 2014). New proposals include the replacement of terms during the course of history and the positing of some intermediate terms that are not directly attested. Attention is paid to the history of the documentation of the systems, as well as native traditions regarding their origins.

1 I am grateful to Patrick McConvell and two anonymous referees for helpful feedback. 


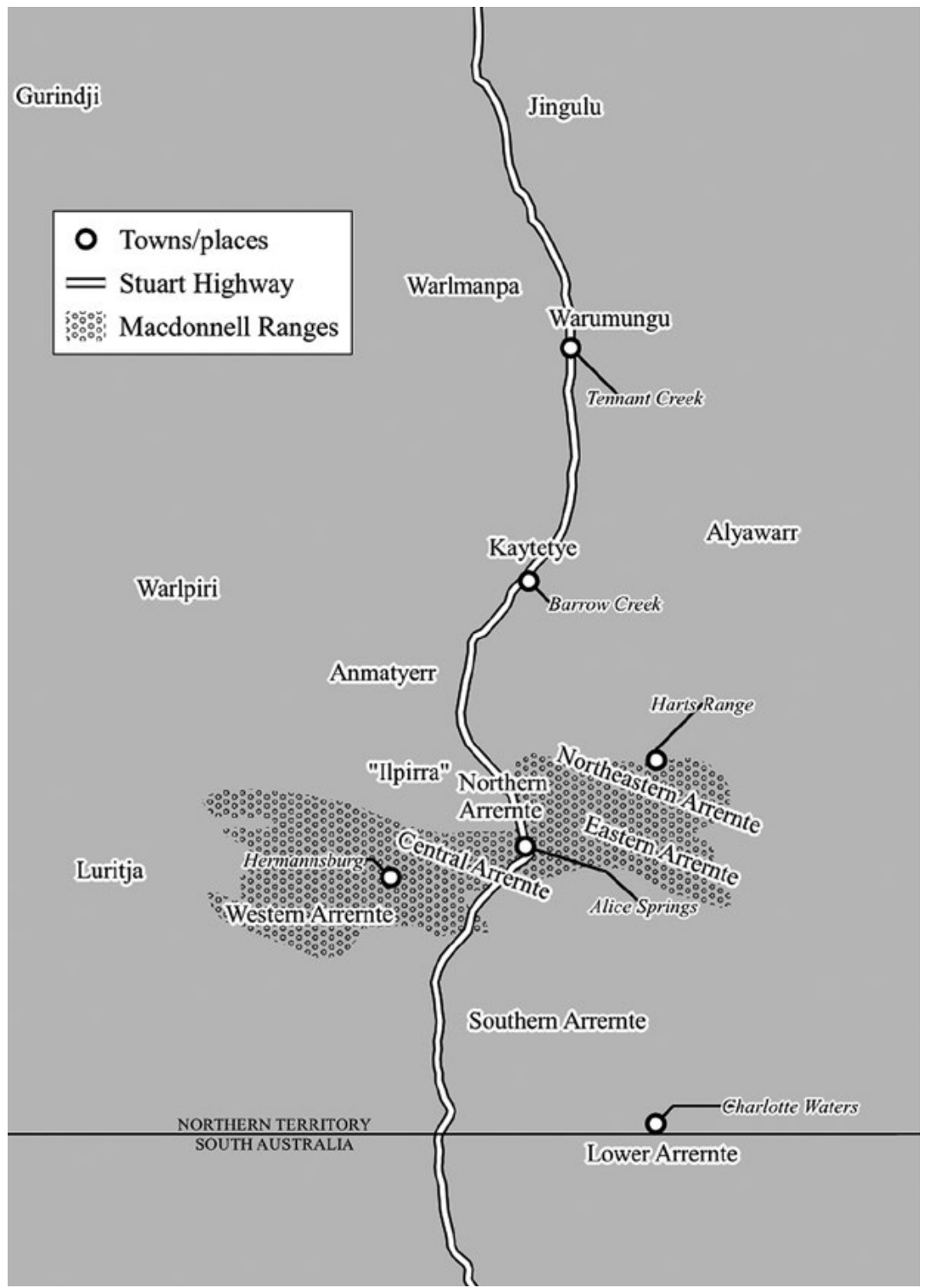

Figure 45: Languages of Central Australia.

Source: Author's work. 


\section{Overview of Systems of the Arandic Peoples and Their Neighbours}

The Arandic languages all include a system of social category terms that are called, in the terminology introduced by Radcliffe-Brown (1918, 1930-31), sections and subsections_-also popularly referred to as 'skins'. The southernmost Arandic group, the Lower Arrernte, have a system of four sections, as shown in Table 41, in which the sections have been given letter codes according to Radcliffe-Brown's practice, but are displayed in an arrangement that follows Spencer and Gillen (1927, p. 445; 1969a [1899], p. 72; cf. 1969b [1904], p. 90). ${ }^{2}$ The sections are arranged into patrimoieties (P and $\mathrm{Q})$, such that a member of each patrimoiety marries a member of the opposite patrimoiety (marriage relations are indicated by the $=$ sign), and a man's child belongs to the same patrimoiety as (but a different section from) their father. The father-child relations are indicated by means of the vertical lines; thus, A's child belongs to section $\mathrm{D}$, and D's child belongs to section A. Mother-child relations are not directly indicated in this display, but can be computed through the mother's partner-thus, the child of a female Penangke (A) is traced through her Perrurle (B) partner and belongs to the Kemarre (C) section. $\mathrm{AC}$ and $\mathrm{BD}$ constitute matrimoieties, although these are not directly displayed. Further, A and B belong to one generation level and $\mathrm{C}$ and $\mathrm{D}$ to another. These generation levels include people related as siblings, spouses, grandparents and grandchildren; each generation level consists of members of sets of alternate generations.

Table 41: Section system of the Lower Arrernte.

\begin{tabular}{|c|c|c|c|c|c|c|}
\hline \multicolumn{2}{|c|}{} & P & & \multicolumn{2}{|c|}{ Q } & \multicolumn{2}{|c|}{} \\
\hline$\rightarrow$ & A & Penangke & $=$ & Perrurle & B & $\leftarrow$ \\
\hline I & & & & & & I \\
\hline$\rightarrow$ & D & Peltharre & $=$ & Kemarre & C & $\leftarrow$ \\
\hline
\end{tabular}

Source: Spencer and Gillen (1927, p. 445).

The eight-term subsection system is illustrated in Table 42, with the skin terms of the Central and Eastern Arrernte (Henderson \& Dobson 1994, p. 41). In a subsection system, each section is divided into two subsections (e.g. A1 and A2). There are four patricouples: A1 + D2, A2 + D1, B1

2 The spelling has been adapted to the system used for Central and Eastern Arrernte. 
$+\mathrm{C} 1$ and B2 + C2. Patrimoieties and generational levels are the same as the four-section system. The eight-term subsection system makes an overt terminological distinction within a section between first and second cross-cousins. Thus, a person in the Penangke (A1) subsection will find their second cousin (e.g. a man's mother's mother's brother's daughter's daughter) in the Perrurle (B1) subsection, but their first cross-cousin (e.g. a man's mother's brother's daughter or father's sister's daughter) in the Angale (A2) subsection. The preferred marriage partner is a second cousin, although a classificatory (but not actual) first cousin may be a secondchoice partner. Thus, a Penangke's preferred wife is Perrurle, as shown by the $=$ sign. In instances in which children result from a marriage other than the preferred one signalled in the table (e.g. in the case of a Penangke father and an Angale mother), the child may take the skin appropriate to the mother (i.e. Peltharre) or the father (i.e. Pengarte), or use both (e.g. Peltharre-Pengarte), perhaps according to the context.

Table 42: Subsection system of the Central and Eastern Arrernte.

\begin{tabular}{|c|c|c|c|c|c|c|c|c|}
\hline \multicolumn{2}{|c|}{ Patrimoiety P } & & Patrimoiety Q & \multicolumn{3}{|c|}{} \\
\hline$\rightarrow$ & & A1 & Penangke & $=$ & Perrurle & B1 & $\leftarrow$ & \\
\hline I & $\rightarrow$ & A2 & Kngwarreye & $=$ & Angale & B2 & $\mid$ & $\leftarrow$ \\
\hline I & I & & & & & & $\mid$ & $\mid$ \\
\hline I & $\rightarrow$ & D1 & Peltharre & $=$ & Kemarre & C1 & $\leftarrow$ & | \\
\hline$\rightarrow$ & & D2 & Pengarte & $=$ & Ampetyane & C2 & & $\leftarrow$ \\
\hline
\end{tabular}

Source: Henderson and Dobson (1994, p. 43).

Moieties are not named; nevertheless, patrimoieties are recognised terminologically in two ways. First, non-singular pronouns in some dialects of Arrernte (as well as in Anmatyerre, Alyawarr and Kaytetye) are marked for differences of social category. Thus, in North-eastern Arrernte, 'we two' is ilanthe if its referents belong to different patrimoieties (e.g. 'I and my spouse' or 'I and my mother'), ilake if the term refers to 'me and my father' or 'me and my brother's child' and ilerne for 'me and my brother or sister' or 'me and my father's father'. The last two forms show that a further distinction is made between generation levels if the referents of the pronoun are within the same patrimoiety. The second linguistic reflex of the patrimoiety division is the fact that there are egocentric terms that distinguish 'people in my patrimoiety' from 'people in the other patrimoiety'. The term for the former is ilakakeye, based on the first-person dual pronoun ilake, which means 'I and my father', or anwakerrakeye, based on the first-person plural pronoun, which means 
'I and my father plus others (all members of the set belonging to different generational levels of the same patrimoiety)'. The term that designates 'other patrimoiety' is alakakeye (based on the third-person dual pronoun alake, which means 'they two related as a person and their father'), or malyanweke, which may be etymologically akin to 'our in-laws' (anweke being the dative form of the historic first-person plural pronoun). Apart from these linguistic reflexes, the patrimoiety distinction plays a certain role in social behaviour: members of the two patrimoieties were observed by Spencer and Gillen to camp separately (see Spencer \& Gillen 1927, p. 229, figure 69) and to play complementary roles in ceremonial rituals. ${ }^{3}$

Spencer and Gillen (1927, pp. 41-2) reported on several Indigenous theories concerning the nature of patrimoieties. The [Central and Northern $]^{4}$ Arrernte refer to the members of the AD and BC moieties as mberga oknirra [akngerre] 'big men' and mberga tungwa 'little men' respectively, with mberga denoting the human body-that is large-bodied versus small-bodied. People of the AD moiety are further distinguished as having straight hair, while BC members are said to have wavy hair. Spencer and Gillen claimed there is no anatomical difference to support either of these distinctions; the results of an examination of hair samples by Dr O. W. Tiegs (Spencer's University of Melbourne colleague) are described in Spencer and Gillen (1927, pp. 597-9 Appendix E: Hair Structure). They also mentioned Carl Strehlow's statement that the [Western] Arrernte formerly used the terms kwatjarinja [kwatyarenye] 'water-dwellers' and alarinja [ahelharenye] 'land-dwellers' to designate the $\mathrm{AD}$ and $\mathrm{BC}$ moieties respectively.

The two generational levels, similar to the patrimoieties, are not named, but there is a term nyurrpe that means 'belonging to the opposite generational level'. Thus, for a person in the A or B sections, all members of the $\mathrm{C}$ and $\mathrm{D}$ sections are nyurrpe, and vice versa. The combinations $\mathrm{A}+\mathrm{B}$ and $\mathrm{C}+\mathrm{D}$ are sometimes referred to as generational moieties.

Groups to the north of the Arandic groups, including the Warlpiri, Warlmanpa and Warumungu, have an eight-subsection system like that of the northern Arandic groups. However, there are two principal differences. Each subsection term in the non-Arandic languages distinguishes

3 'The existence of the two primary divisions is very evident during the performance of such ceremonies as the Engwura' (Spencer \& Gillen 1927, p. 41).

4 Modern spellings of Spencer and Gillen's Arrernte terms are given in square parentheses where these are known. 
the gender of its members. Terms for males begin with $j$ (equivalent to the $t y$ of Arandic orthographies), while terms for females begin with $n$. The Warlpiri terms are given in Table 43, using the same arrangement as Table $42 . .^{5}$

Table 43: Subsection system of the Warlpiri (adult terms only).

\begin{tabular}{|c|c|c|c|}
\hline A1 & $\begin{array}{c}\text { Japanangka } \\
\text { Napanangka }\end{array}$ & $\begin{array}{c}\text { Jupurrurla } \\
\text { Napurrurla }\end{array}$ & B1 \\
\hline A2 & $\begin{array}{c}\text { Jungarrayi } \\
\text { Nungarrayi }\end{array}$ & $\begin{array}{c}\text { Jangala } \\
\text { Nangala }\end{array}$ & B2 \\
\hline D1 & $\begin{array}{l}\text { Japaljarri } \\
\text { Napaljarri }\end{array}$ & $\begin{array}{l}\text { Jakamarra } \\
\text { Nakamarra }\end{array}$ & C1 \\
\hline D2 & $\begin{array}{l}\text { Japangardi } \\
\text { Napangardi }\end{array}$ & Nampijijna & C2 \\
\hline
\end{tabular}

Source: Meggitt (1962, p. 165); Laughren (1982, p. 76).

A second characteristic of the northern systems is that they include separate junior terms, which also make a distinction of gender. Thus, there are four terms for each subsection: a pair of masculine and feminine adult terms and a pair of corresponding gendered junior terms. The north-western Arandic languages Anmatyerre and Kaytetye share the gendered junior terms of their western neighbours, but only have normal Arandic (with a few exceptions in Kaytetye) gender-neutral terms for their adult terms. The complete Kaytetye system is presented in Table 44, where each cell gives the adult name, the junior male name and the junior female name. ${ }^{6}$

Table 44: Subsection system of the Kaytetye (including junior terms).

\begin{tabular}{|c|c|c|c|c|c|c|c|}
\hline & & & Patrimoiety $\mathrm{P}$ & & Patrimoiety $Q$ & & \\
\hline$\vec{i}$ & & A1 & $\begin{array}{c}\text { Apenangke } \\
\text { Tyaname } \\
\text { Ngamane }\end{array}$ & B1 & $\begin{array}{c}\text { Pwerle } \\
\text { Tywerlame } \\
\text { Ngamperle }\end{array}$ & $\leftarrow$ & \\
\hline | & $\overrightarrow{\mid}$ & $\mathrm{A} 2$ & $\begin{array}{c}\text { Kngwarreye } \\
\text { Tywekertaye } \\
\text { Ngapete }\end{array}$ & B2 & $\begin{array}{l}\text { Thangale } \\
\text { Tyangkarle } \\
\text { Ngangkale }\end{array}$ & 1 & $\leftarrow$ \\
\hline | & $\rightarrow$ & D1 & $\begin{array}{l}\text { Kapetye } \\
\text { Tyapalye } \\
\text { Ngalyerre }\end{array}$ & C1 & $\begin{array}{l}\text { Akemarre } \\
\text { Tyakarre } \\
\text { Watyale }\end{array}$ & $\leftarrow$ & 1 \\
\hline
\end{tabular}

5 For the terms and structure of Warlpiri skin names, see Laughren (1982).

6 See Turpin and Ross (2012, pp. 809-10) for the forms. The junior terms are used for children. Since the second half of the twentieth century, when the use of surnames became common, junior skin names have often been used as surnames by people who otherwise lacked a surname, and these names have continued in use through adulthood. 


\begin{tabular}{|l|l|l|l|l|l|l|}
\hline \multicolumn{2}{|l|}{} & Patrimoiety P & Patrimoiety Q & \multicolumn{2}{|c|}{} \\
\hline$\rightarrow$ & D2 & $\begin{array}{c}\text { Apengarte } \\
\text { Tyapeyarte } \\
\text { Ngampeyarte }\end{array}$ & C2 & $\begin{array}{c}\text { Ampetyane } \\
\text { Tyamperlke } \\
\text { Mpetyakwerte }\end{array}$ & $\leftarrow$ \\
\hline
\end{tabular}

Source: Turpin and Ross (2012, pp. 809-10).

The remainder of this chapter will be devoted to describing what is known about the history of the Arandic systems. We address questions of when, where and in what manner the terminology of the Arandic languages developed.

\section{Historical Explanations in the Literature}

The historical scenario regarding Arandic skins that has been presented in previous scholarship includes the following points:

1. All Arandic terms are assumed, on the basis of their formal similarities, to have been borrowed from languages to the north(west).

2. Geographically, the southern and eastern varieties have only four terms, but the remaining groups each have eight terms.

3. The four-term system is interpreted as the earlier system. It is assumed that there were two successive spreadings of terms from the north.

4. There is historical evidence that some of the Arandic groups adopted the eight-term system only in the 1880s, receiving this system from their northern neighbours.

5. The formal differences between the Arandic terms and those of their neighbours - in particular, differences involving the initial consonant (C) and vowel (V) of the names-need to be accounted for with respect to the relative chronology of the Arandic sound changes and the borrowing of these terms.

Spencer and Gillen, in particular, have emphasised the fourth point (which will be further explored in the sub-subsection 'Central Arrernte'):

The division into eight has been adopted (or rather the names for the four new divisions have been), in recent times by the Arunta tribe from the Ilpirra tribe which adjoins the former on the north, and the use of them is, at the present time, spreading southwards. (Spencer \& Gillen 1969a [1899], p. 72) 
The names derived, so the natives say, from the Ilpirra, a strong tribe living to the north of the Arunta, have gradually spread southwards. (Spencer \& Gillen 1927, p. 42)

In regard to $\ldots$ the introduction of eight, instead of four class names, we know, as a matter of fact, that this change has actually entered the Arunta from the north and at the present moment is spreading southwards. (Spencer \& Gillen 1969b [1904], p. 20)

Elkin (1939-40, pp. 199-200) drew out the inferences listed in points 2 and 3:

In the northern parts of the Aranda tribe, as Spencer and Gillen point out (The Arunta, Vol. I, p. 44), each of the four sections was divided into two parts, and the old name was retained for one part or subsection ... The new terms, like the old four, came from the north and north-west, as a comparison with the subsection terms of the Loritja and Warramunga make clear ... The Aranda told Spencer and Gillen that they had received the system from the north. Apparently they had adopted the section system first, and later the subsection system.

McConvell (1985; 1996, pp. 130-2) presented a scenario for the spread of sections and subsections to the Arandic languages. The section terms derive ultimately from the Pilbara region, but spread eastwards as far as the Victoria River District, where Jaminjungan languages were spoken. There, they acquired gender prefixes $j a$ - [tya- $]$ masculine and na-feminine, then diffused southward through the Warlpiri to Arandic, perhaps 800-500 years ago. These terms were subject to the first phase of Arandic sound changes, which deleted the first consonant and the following vowel-for example, changing *Tyapanangka to *Penangke. Later, perhaps around 500 years ago, in the Victoria River area, an eight-term subsection developed out of the combination of a south-western and north-eastern (from the perspective of the Northern Territory) section system and spread south by the same route as earlier sections. These additional terms were subject to a different phonological change in Arandic, which deleted the original consonant but not the following vowel-for example, *Tyapangarti became *Apengarte. This second borrowing took place around 1850, according to the account given in Spencer and Gillen (1969a [1899], p. 72). The processes by which the terms were modified in the Arandic languages will be explored further in the section 'Borrowing, Sound Change and Relative Chronology'. 
The following discussion will examine the historical aspects of skin names in greater detail, paying attention to the early documentary sources, relations between five different Arandic groups (Lower Arrernte, Central and Western Arrernte, Anmatyerre, Alyawarr and Kaytetye) and relations with three external groups (Warlpiri, Warumungu and Warlmanpa). I highlight terminological differences between Arandic groups and include separate discussions on the origin of skin terms in each. I also revisit the issue of how the borrowing of terms interacts with the historical sound changes and discuss some of the possible mechanisms of adoption of subsections, based on local traditions. Finally, I make some inferences about the absolute dates for the adoption of the terms. Reconciliation of the information in the old sources will have to await another occasion.

\section{Survey of Arandic Groups}

\section{Lower Arrernte}

The Arandic section names were first documented in 1875. In that year, the stationmaster Christopher Giles supplied Taplin with the following information concerning the Aboriginal people in the vicinity of the Charlotte Waters Telegraph Station, whose tribal name was reported as Antakerrinya and whose language was said to be Arrinda (Giles 1879, pp. 89, 91). ${ }^{7}$ There were four 'class-names', spelled: Paroolal Parroola, Panúngkal Poonungka, Booltára and Koomurra. Essentially, the same terms were reported over the next two decades for other areas where Arrernte was spoken, including Alice Springs and Hermannsburg Mission. Table 45 gives the terms as spelled in various sources, as well as their representation in modern orthography. ${ }^{8}$ Giles (1879) is the earliest source on Lower Arrernte. Schulze's (1891) terms are taken from the first missionary report on the subsection system among the Western Arrernte (see the

7 Cf. Gillen's comment in a letter dated 29 January 1903 that 'the Southern Arunta often speak of themselves as Antikirunya' (Mulvaney et al. 1997, p. 434) — that is, Antekerrenye, which means 'southern'. In the twentieth century, the term 'Antakarinya' became established as the name of a group of speakers of Western Desert dialects in the area west of Lake Eyre. This situation is apparently indicated already in Gillen's letter of 30 July 1897: 'There is a tribe up the Albinga [Alberga] and spreading away to the Musgraves who call themselves the Antikerinya and speak the Luritcha [Western Desert] tongue' (Mulvaney et al. 1997, p. 178).

8 In addition to the usual problems that non-linguists had in spelling words in Australian languages (variability of voiced and voiceless consonants like $b$ and $p$, the ambiguity of English $u$ [e.g. in put versus putt] and failure to signal two different kinds of $r$-sound), Arandic languages include a central vowel spelled $e$ and pronounced something like the $e$ of English the, which was perceived in many different ways. 
sub-subsection 'Western Arrernte'). Stirling's (1896) terms are from his report on the Horn Scientific Expedition to Central Australia and is not specific as to which subgroup of the Arrernte it applies to. Gillen's (1896) terms are also from the report on the Horn Expedition; it can be taken to reflect the central dialect of Arrernte spoken at Alice Springs, where Gillen was the telegraph stationmaster. Spencer and Gillen's (1969a [1899], p. 69) terms reflect later research by Gillen in association with Spencer, mainly concerning the same Central Arrernte group. Mathews's (1899) terms represent data supplied by a correspondent and relate to the Eastern Arrernte of Harts Range and Arltunga. Strehlow's (n.d.) data are from his unpublished dictionary compiled in 1909 and represent the Western Arrernte of Hermannsburg Mission. Breen's (2000) terms denote the forms given in the dictionary of Western Arrernte. Finally, Henderson and Dobson's (1994, p. 41) terms represent the four-term system that is still in effect in the modern north-eastern dialect of Arrernte.

Table 45: Arrernte section names according to sources.

\begin{tabular}{|l|l|l|l|l|}
\hline & A & B & C & D \\
\hline Giles 1879 & $\begin{array}{l}\text { Panúngka/ } \\
\text { Poonungka }\end{array}$ & $\begin{array}{l}\text { Paroola/ } \\
\text { Parroola }\end{array}$ & Koomurra & Booltára \\
\hline Schulze 1891 & Bunanka & Purula & Gomara & Beltara \\
\hline Stirling 1896 & Panunga & Purula & Kumarra & $\begin{array}{l}\text { Pultarra/ } \\
\text { Pultharra }\end{array}$ \\
\hline Gillen 1896 & Panunga & Purula & Kumarra & Pultarra \\
\hline Spencer \& Gillen 1899 & Panunga & Purula & Kumara & Bulthara \\
\hline Mathews 1899 & Panungka & Parulla & Koomara & Bultara \\
\hline Strehlow n.d. & Pananka & Purula & Kamara & Paltara \\
\hline Breen 2000 & Penangke & Pwerrerle & Kemarre & Peltharre \\
\hline Henderson \& Dobson 1994 & Penangke & Perrurle & Kemarre & Peltharre \\
\hline
\end{tabular}

Source: Breen (2000), Giles (1879), Gillen (1896), Henderson and Dobson (1994, p. 41), Mathews (1899), Schulze (1891), Spencer and Gillen (1899), Stirling (1896) and Strehlow (n.d.).

\section{Arrernte}

\section{Western Arrernte}

The first reports of an eight-term subsection system came from missionaries associated with the Hermannsburg Mission in Western Arrernte territory. Schulze (1891, pp. 223-7) included a section on the 'eight-class system', which spelled out which groups could intermarry and what skin their 
offspring belonged to (see Table 45 for Schulze's spelling of the traditional four names and Table 46 for the four new terms). The eight-term system allows 'under certain circumstances' (Schulze 1891, p. 224) for an alternative marriage between A1 and B2 (and generally between the 1 and 2 members of each section), in terms of Table 42. Schulze claimed that the child's subsection is always determined by that of its father. Schulze's system has the children of a male Penangke (A1 in Table 42) in the Peltharre subsection and those of a Kngwarreye in Pengarte - which does not agree with the modern system or that described by Spencer and Gillen (1969a [1899], p. 70) for Central Arrernte; however, it would be accurate if the skin of the child is determined by that of the mother and if some of the marrying pairs were of the alternative type.

In Stirling's (1896, p. 47) discussion of the Arrernte section system, he reported that he was unable to find confirmation of Schulze's system and noted that another Hermannsburg missionary, Reverend H. Kempe, in writing to Howitt, 'admit[ted] only the four classes here mentioned'in the same tribe that Schulze described. Stirling (1896, p. 48) reported that Schulze's four supplementary names 'were perfectly well recognised by the natives, and were stated to be the corresponding or equivalent names of the four divisions in other neighbouring tribes, though what these tribes were I could not gather further than that a northerly habitat was vaguely indicated'.

An eight-term system was also given in Strehlow's (n.d.) dictionary of Western Arrernte, by Spencer and Gillen (1969a [1899]) for Central Arrernte and by Mathews (1899) for Eastern Arrernte. Table 46 gives the second set of skin names that were provided by various authorities.

Table 46: Additional Arrernte skin names according to sources.

\begin{tabular}{|l|l|l|l|l|}
\hline & A2 & B2 & C2 & D2 \\
\hline Schulze 1891 & Knuraia & Ngala & Mbutjana & Pungata \\
\hline Spencer \& Gillen 1899 & Uknaria & Ungalla & Umbitchana & Appungerta \\
\hline Mathews 1899 & Knurraia & Ngala & Mbutjana & Pungata \\
\hline Strehlow n.d. & Knuraia & Ngala & Mbitjana & Bangata \\
\hline Breen 2000 & Kngwarreye & Ngale & Mpetyane & Pengarte \\
\hline Henderson \& Dobson 1994 & Kngwarraye & Angale & Ampetyane & Pengarte \\
\hline
\end{tabular}

Source: Breen (2000), Henderson and Dobson (1994, p. 42), Mathews (1899, p. 72), Schulze (1891), Spencer and Gillen (1899, p. 72) and Strehlow (n.d.). 


\section{Central Arrernte}

Gillen (1896, pp. 162-3) reported the same four class names that were in use among the Lower Arrernte for the 'McDonnell Range tribe'. However, it is apparent that the situation had already somewhat altered by the time the report was published. In a letter to Spencer on 31 January 1896, Gillen reported that the eight-class system was adopted by the Arrernte during the preceding 15 years (i.e. from 1880) and that the system and its terms were taken over from their northern neighbours, whom he called the Chitchica:

The 8 classes of which the missionaries spoke is the class system of the Chitchica which I was surprised to find is rapidly being adopted throughout the McDonnell Ranges. The blacks tell me that they first began to adopt it some fifteen years ago ... and that during the last two or three years it has almost come into general use. Questioned as to why they should adopt the system of another tribe, my old alaartunja says, 'That one very good him makeum walk straight'. The blacks about the Mission district [Hermannsburg] and Eastern McDonnells who mix a great deal with the Chitchica were the first to adopt the system-If you compare my Arunta table of relationships with the Eight Class system you will see at a glance how it simplifies matters. (Mulvaney et al. 1997, p. 96)

This important statement needs to be deconstructed if we are to discern which group was the source of the names and which subgroup of the Arrernte was the first to adopt them. In this scenario, the source is given as the Chitchica. In a later letter (14 July 1896), Gillen corrected the term Chitchica: "This should be "Ilpira", not Chitchica which means foreigners generally, it is from the "Ilpira" that these people have bagged the 8 classes' (Mulvaney et al. 1997, p. 130). This correction was repeated several times in subsequent letters to Spencer (Mulvaney et al. 1997, pp. 110-11, 130, 169). However, we still need to ask: who were the Ilpira? It is clear from a careful reading of Spencer and Gillen that their Ilpira or Ilpirra did not denote the (eastern) Warlpiri, as did the term Arlpere in modern Arrernte, ${ }^{9}$

9 The glossary compiled by David Wilkins and Alison Petch and included in Mulvaney et al. (1997, pp. 487-533) incorrectly makes this misleading identification as well, when it glosses Ilpirra as Warlpiri, adding the comment: 'Ilpira or Ilpirra particularly refers to a division of the Warlpiri on the Anmatyerre side' (Mulvaney et al. 1997, p. 505). Meggitt (1962, p. 168) also took the 'Ilpirra tribe' of Spencer and Gillen (1969a [1899], p. 90) as referring to the 'south-eastern Walbiri'. McConvell (1985, p. 6) likewise assumed that this denoted the Warlpiri: 'Spencer and Gillen (1927) tell us that the Aranda originally had a section system and that the four extra terms (A2, B2, C2, D2) were borrowed, from the Warlpiri to the north, not long beforehand'. 
but rather the Anmatyerre. ${ }^{10}$ Gillen commented in a letter dated 29 January 1903: 'The Ilpira and Unmatjira are really one tribe and at anyrate [sic] the Arunta always apply the term Ilpira to them' (Mulvaney et al. 1997, p. 343); and later on 1 February 1903: 'It's a funny thing that we never heard the term Unmatjira amongst the Arunta who always speak of them as Atchichika "foreigners" or "strangers"' (Mulvaney et al. 1997, p. 435). They did not encounter the name Unmatjira [Anmatyerre] until they met representatives of the more northern part of this tribe while at Barrow Creek in June 1901; the first mention in Gillen's diary is in the entry for 17 June (Gillen 1968, p. 126). The referent of the name Ilpirra has obviously changed during the twentieth century; but a close association between the Anmatyerre and the Warlpiri apparently persisted. ${ }^{11}$

Which subgroup of the Arrernte was the first to adopt the extra terms? The answer to this question depends on how one is to interpret the words in italics in the quotation from Gillen's letter: 'and Eastern McDonnells'. The editors of Gillen's letters informed us that 'editorial insertions are always in italics' (Mulvaney et al. 1997, p. viii). However, I do not see any basis for this insertion. Without it, Gillen denoted the Arrernte at Hermannsburg Mission as the first adopters of the new system. In a letter dated 7 November 1895, he had already described the 'Mission station' as a place 'where the Looritcha, Arunta and Chichica intermingle' (Mulvaney et al. 1997, p. 88). Thus, it appears that soon after the founding of the mission in 1877, the Western Arrernte, began to use the subsection system of their northern neighbours, the Anmatyerre, some of whom spent time at Hermannsburg. Other Arrernte along the MacDonnell Ranges also took up the use of this system during the course of the next 15 years, with the result that its use became established in the Alice Springs area by 1895. This history accounts for the fact that the skin names belonging to the second set given by Spencer and Gillen for the Arrernte are identical to those given for their Ilpirra (i.e. the Anmatyerre).

10 For example, a display of the relative locations of the Arunta, Ilpirra, Illeowra [Alyawarr] and Kytiche [Kaytetye] in Gillen's letter of 25 April 1896 (Mulvaney et al. 1997, p. 112) places the Ilpirra to the north-west of the Arunta, west of the Illeowra and southwest of the Kytiche, which accurately represents the location of the group that has been called Anmatyerre-cf. the map in Strehlow (1947), where the name Unmatjera is attached to the whole area that is designated Ilpirra on Spencer and Gillen's maps (e.g. Spencer \& Gillen 1927, p. 5).

11 Strehlow (1947, p. 52) reported that the Northern Arrernte asserted the purity of their language versus that of other Arandic groups: 'The Western Aranda and the Southern Aranda are both halfLoritja; our neighbours, the Unmatjera, are half-Ilpara'. Meggitt (1962, p. 40) reported that the Warlpiri regarded the 'Yanmadjari' as 'half-Walbiri and one people with us'. 


\section{Southern Arrernte}

The Southern Arrernte are (linguistically) a subgroup of the Western Arrernte. The eight-term system was apparently introduced to the Southern Arrernte some time after it was received by the Western Arrernte-perhaps during the early part of the twentieth century, judging from the following account in Strehlow (1947, p. 72):

In contrast to their Northern and Western tribesmen whose groups were each divided into eight classes, the Southern Aranda had their marriages regulated by a four-class system only; and the Southern men stuck to their own traditions tenaciously. On my visit to Horseshoe Bend in 1933 I found there two old Southern men who addressed one another as 'brother', though they ostensibly belonged to two different classes. When I asked them how they could use this appellation when they were separated by reason of their differing classes, they replied that, in the old days, they had both belonged to the same marriage class. Their own group, however, had become almost extinct long since; and strangers who had the eight-class system had come in from the Northern groups and from bordering Loritja [Western Desert] territories. The two old Southern men had been put into different classes by these newcomers, since one of them had married a wife who came from an eight-class group; and the marriage had now been 'legalized' according to the ideas of the strangers. They finished their explanation with some very scathing remarks about the Northern Aranda who had had the presumption of attempting to force their own system upon old Southern territory, where men had lived orderly lives under the four-class system as far back as memory and tradition could reach.

The four-class system is the better of the two for us Southerners; we cannot understand the eight-class system. It is mad and purposeless, and only fit for such crazy men as the Northern Aranda are; we did not inherit such stupid traditions from our fathers.

From the modern Southern Arrernte wordlist (Swan \& Cousen 1993), one can infer that the eight-term system has persisted-although the wordlist only lists five of the expected terms: Penangke and Kemarre from set 1, and Ngale, Mpetyane and Pengarte from set 2.

\section{Anmatyerre}

As previously mentioned, Spencer and Gillen's Ilpira/Ilpirra and Unmatjira both correspond to the modern Anmatyerre group. Table 47 presents the skin names given for Ilpirra by Spencer and Gillen (1969a [1899], p. 90), Unmatjira by Gillen (1968, p. 151), Central Anmatyerre 
and Eastern Anmatyerre by Green (2010, p. 743), and Iliaura [Alyawarr] by Spencer and Gillen (1969a [1899], p. 90). Comparing the forms, we note that the final vowel, which is spelled with an $a$ by Spencer and Gillen and with an $e$ in modern orthographies of E/C Arrernte and Kaytetye, is omitted in the modern orthography of Anmatyerre (and Alyawarr). In her orthography, Green (2010, p. 744) also omitted initial vowels, while noting that 'many words in Arandic languages may be pronounced either with or without the initial $a$ vowel'. A systematic phonetic difference is that modern Central Anmatyerre lacks the prestopped nasals found in other Arandic varieties: this accounts for the absence of the $k$ in Ngwarray. The only substantive difference between Gillen's Unmatjira and both Spencer and Gillen's Ilpirra and modern Central Anmatyerre is that the former has a form Thungalla for B2; this must be identified with the Thangale characteristic of Anmatyerre's north-eastern neighbour Kaytetye. We can assume that around the year 1900, some subgroups of the Anmatyerre, as well as a subgroup of the Alyawarr, had adopted the Kaytetye term in place of Angale, but subsequently dropped Thangale in favour of the more widespread Angale. The other aberrant forms, shown in boldface in Table 47, are D1 Petyarre and B1 Pwerle, which are shared with Alyawarr. The 'Iliaura' forms are further discussed in the next section.

Table 47: Anmatyerre skin names.

\begin{tabular}{|l|l|l|l|l|l|}
\hline & $\begin{array}{l}\text { Ilpirra } \\
\text { (Spencer \& } \\
\text { Gillen) }\end{array}$ & $\begin{array}{l}\text { Unmatjira } \\
\text { (Gillen) }\end{array}$ & $\begin{array}{l}\text { Central } \\
\text { Anmatyerre } \\
\text { (Green) }\end{array}$ & $\begin{array}{l}\text { Eastern } \\
\text { Anmatyerre } \\
\text { (Green) }\end{array}$ & $\begin{array}{l}\text { lliaura } \\
\text { (Spencer \& } \\
\text { Gillen) }\end{array}$ \\
\hline A1 & Panunga & Panunga & Penangk & Penangk & Apanunga \\
\hline A2 & Uknaria & Uknaria & Ngwarray & $\begin{array}{l}\text { Kngwarray/ } \\
\text { Ngwarray }\end{array}$ & Uknaria \\
\hline D1 & Bulthara & Bulthara & Peltharr & Petyarr & Appitchara \\
\hline D2 & Appungerta & Appungerta & Pengart & Pengart & Appungerta \\
\hline B1 & Purula & Purula & Pwerrerle & Pwerl & Upilla \\
\hline B2 & Ungalla & Thungalla & Ngal & Ngal & Thungalla \\
\hline C1 & Kumara & Kumara & Kemarr & Kemarr & Akumara \\
\hline C2 & Umbitchana & Umbitchana & Mpetyan & Mpetyan & Umbitchana \\
\hline
\end{tabular}

Source: Gillen (1968, p. 151), Green (2010, p. 743) and Spencer and Gillen (1969a [1899], p. 90). 


\section{Alyawarr}

The Alyawarr, in the north-eastern part of Arandic territory, have a system of four section names rather than eight subsection terms. It might be assumed that these should be the same four original terms that are found among the Lower Arrernte. However, there are four facts that contradict this expectation, each of which requires a historical explanation.

1. The $\mathrm{A}$ term is not the expected $(A)$ penangke from the first set, but Kngwarreye (i.e. A2 from the second set).

2. Alyawarr's B term is not the Perrurle of E/C Arrernte or the Pwerrerle of Central Anmatyerre, but Pwerle (or Apwerle), like the Pwerle of Kaytetye.

3. Alyawarr's $\mathrm{D}$ term is not Peltharre, but an isolated form Apetyarre.

4. Spencer and Gillen (1969a [1899], p. 90) gave for their 'Iliaura' tribe an eight-member subsection system.

I suggest the following explanations. For the first issue, I propose that a subgroup of the Alyawarr was in close contact with neighbours (Anmatyerre and/or Kaytetye) who had the subsection system. From the Alyawarr viewpoint, the system of their western neighbours had two terms that were equivalent to each of their own; therefore, they could regard them as synonyms. At some point, they substituted the alternate term Kngwarreye for their earlier Apenangke. ${ }^{12}$ This innovation was then copied by all Alyawarr who had a four-term system. This probably happened before the eastward migration of some Alyawarr to Lake Nash in far west Queensland, which took place between 1925 and c. 1935, according to Yallop (1969, p. 192). This scenario assumes that Alyawarr once had the A term Apenangke. The second problem is easily solved by assuming that the Alyawarr obtained their B term via Kaytetye, which also has Pwerle, or possibly from Warumungu, where the form was Juppurlu. For the $\mathrm{D}$ term (A)petyarre, I likewise propose a borrowing from Kaytetye, since this language provides a bridge to its ultimate source in Warlmanpa, as explained in the next section. The fourth question, concerning Spencer and Gillen's eight-term Alyawarr group, can be resolved by positing that at least one group that once identified as Alyawarr had indeed adopted the subsection system, but that they subsequently changed their affiliation to Eastern Anmatyerre. In a letter dated 29 January 1903, Gillen commented:

12 For a possible parallel, cf. southern Nyangumarta, where the section name Panaka was substituted with Jangarla by some people due to a death (Sharp 2004, p. 20). 
'They [the Ilpira and Unmatjira] are also so mixed up with the Illiaura that is difficult to tell where one ends and the other begins' (Mulvaney et al. 1997, p. 434). The forms quoted by Spencer and Gillen (1969a [1899], p. 90) for the modern Eastern Anmatyerre are almost identical to those given by Green (2010, p. 743)—see Table 47. The only significant difference is that Spencer and Gillen's B2 form, like Gillen's Anmatyerre, is Thangale, which seems to have been borrowed from Kaytetye. Thus, Spencer and Gillen's Anmatyerre and Iliaura data demonstrate that there were local variants of the skin system within the larger groups of Arandic peoples.

\section{Kaytetye}

The first systematic recording of the 'Kytiche' (as Gillen called them) subsection names was done by Gillen at the end of 1895, according to his letters to Spencer (Mulvaney et al. 1997, pp. 96, 113). There is evidence that the Kaytetye already had the eight-subsection system by 1874: the names of the alleged perpetrators of the 1874 attack on the Barrow Creek Telegraph Station, given in Vallee (2006, p. 113), are recognisable as subsection names belonging to the second set of skin names: Conarie [Kngwarreye], Apogita [Apengarte], Umpijamma [Ampetyane] and Songalla [Thangale.$^{13}$

The junior subsection names, which Kaytetye and some of the Anmatyerre share with Warlpiri, and which distinguish gender (unlike the main terms), were already in place by 1901 . This can be concluded from the fact that Gillen's diary (1968, pp. 163-4; cf. Mulvaney et al. 1997, pp. 341-2) of his and Spencer's 1901 fieldwork at Barrow Creek names two children by their junior names: a boy Tchanama [Tyaname] and a girl Nun-galla $\left[\right.$ Ngangkarle..$^{14}$

Even before Gillen's study, Howitt and Fison (1889, p. 44) published a set of eight names, with male and female terms, obtained through Allan Giles of Tennant Creek. ${ }^{15}$ These are said to be the names of 'Waramunga'; in reality, the masculine terms are Kaytetye and the feminine terms are

13 Gillen (1968, pp. 144, 168) identified a Thungalla [Thangale] man named Arabinya-urungwinya (cf. p. 120) as having been implicated in this attack.

14 For a detailed study of junior skin names, see Koch and Simpson (forthcoming).

15 The same data and analysis are given in a letter from Fison to Howitt, dated 14 July 1884. 
Warumungu ${ }^{16}$ Mathews (1899, p. 77) published a similar list, purporting to be the male and female terms for the 'Warramonga'. These along with Spencer and Gillen's (1969a [1899], p. 90) published 'Kaitish' list are given in Table 48. The final terms in each cell of Table 48 are the modern Kaytetye terms (in the 'masculine' column) from the dictionary (Turpin $\&$ Ross 2012) ${ }^{17}$ and the modern Warumungu female terms (in the 'feminine' column) from Simpson (2002).

Table 48: Kaytetye (and Warumungu feminine) skin names according to sources.

\begin{tabular}{|c|c|c|c|}
\hline & Source & Masculine & Feminine \\
\hline $\mathrm{A} 1$ & $\begin{array}{l}\text { Howitt \& Fison } 1889 \\
\text { Mathews } 1899 \\
\text { Spencer \& Gillen } 1899 \\
\text { Turpin \& Ross } 2012 \text { / } \\
\text { Simpson } 2002\end{array}$ & $\begin{array}{l}\text { Apononga } \\
\text { Aponunga } \\
\text { Apanunga } \\
\text { Penangke }\end{array}$ & $\begin{array}{l}\text { Napononga } \\
\text { Napanunga } \\
\text { Napanunga } \\
\text { Nappanangka }\end{array}$ \\
\hline $\mathrm{A} 2$ & $\begin{array}{l}\text { Howitt \& Fison } \\
\text { Mathews } \\
\text { Spencer \& Gillen } \\
\text { Turpin \& Ross }\end{array}$ & $\begin{array}{l}\text { Ungerai } \\
\text { Ungary } \\
\text { Uknaria } \\
\text { Kngwarraye }\end{array}$ & $\begin{array}{l}\text { Namajili } \\
\text { Namagillie } \\
\text { Namigilli } \\
\text { Namikili }\end{array}$ \\
\hline D1 & $\begin{array}{l}\text { Howitt \& Fison } \\
\text { Mathews } \\
\text { Spencer \& Gillen } \\
\text { Turpin \& Ross / Simpson }\end{array}$ & $\begin{array}{l}\text { Kabaji } \\
\text { Kabajee } \\
\text { Kabidgi } \\
\text { Kapetye }\end{array}$ & $\begin{array}{l}\text { Kabaji } \\
\text { Nalcharrie } \\
\text { Naltjeri } \\
\text { Naljarri }\end{array}$ \\
\hline D2 & $\begin{array}{l}\text { Howitt \& Fison } \\
\text { Mathews } \\
\text { Spencer \& Gillen } \\
\text { Turpin \& Ross / Simpson }\end{array}$ & $\begin{array}{l}\text { Apongardi } \\
\text { Apungata } \\
\text { Appungerta } \\
\text { Pengarte }\end{array}$ & $\begin{array}{l}\text { Napongardi } \\
\text { Napungartie } \\
\text { Napungerta } \\
\text { Nappangarti }\end{array}$ \\
\hline B1 & $\begin{array}{l}\text { Howitt \& Fison } \\
\text { Mathews } \\
\text { Spencer \& Gillen } \\
\text { Turpin \& Ross / Simpson }\end{array}$ & $\begin{array}{l}\text { Opala } \\
\text { Opalla } \\
\text { Purula } \\
\text { Pwerle }\end{array}$ & $\begin{array}{l}\text { Narila } \\
\text { Naralu } \\
\text { Naralu } \\
\text { Narrurlu }\end{array}$ \\
\hline B2 & $\begin{array}{l}\text { Howitt \& Fison } \\
\text { Mathews } \\
\text { Spencer \& Gillen } \\
\text { Turpin \& Ross / Simpson }\end{array}$ & $\begin{array}{l}\text { Tungeli } \\
\text { Tungulli } \\
\text { Thungalla } \\
\text { Thangale }\end{array}$ & $\begin{array}{l}\text { Nungeli } \\
\text { Nungalli } \\
\text { Nungalla } \\
\text { Nangali }\end{array}$ \\
\hline C1 & $\begin{array}{l}\text { Howitt \& Fison } \\
\text { Mathews } \\
\text { Spencer \& Gillen } \\
\text { Turpin \& Ross / Simpson }\end{array}$ & $\begin{array}{l}\text { Akamara } \\
\text { Akamarra } \\
\text { Akomara } \\
\text { Kemarre }\end{array}$ & $\begin{array}{l}\text { Nakamara } \\
\text { Nakomara } \\
\text { Nakomara }\end{array}$ \\
\hline
\end{tabular}

16 However, the D1 term Kapaji is used for the feminine as well as the masculine instead of the expected Naljarri, and the C2 feminine Tampajona is the Warumungu masculine form.

17 Note that the dictionary standardises the spelling of all Kaytetye skin names with an initial consonant; this can be compared to Table 44, which includes the initial vowel that was typically pronounced in the 1970s. 


\begin{tabular}{|l|l|l|l|}
\hline & Source & Masculine & Feminine \\
\hline C2 & Howitt \& Fison & Ampajona & Tampajona \\
& Mathews & Ampajona & Lambein \\
& Spencer \& Gillen & Umbitchana & Nambin \\
& Turpin \& Ross / Simpson & Mpetyane & Nampin \\
\hline
\end{tabular}

Source: Howitt and Fison (1889), Mathews (1899), Spencer and Gillen (1899), Simpson (2002) and Turpin and Ross (2012).

Three features of the Kaytetye set require explanation. First, the B1 term is Pwerle rather than the $P(w)$ errurle expected on the basis of Arrernte and Anmatyerre. ${ }^{18}$ This is easily accounted for by assuming that it was borrowed not from Warlpiri Jupurrurla but from Warumungu or Warlmanpa Jup( $p$ ) urla, which in common with a few other northern neighbours has lost the third syllable (see McConvell 1985, pp. 4-5).

Second, the B2 form Thangale includes an initial consonant, unlike (A)ngale of other Arandic languages. It has apparently been borrowed from Warlpiri Jangala or Warumungu Jangali without the normal initial truncation (see the section 'Arandic Phonology, Sound Change and Borrowing Patterns'). Spencer and Gillen's phonetic rendition of the name indicates that the initial consonant was pronounced as a dental (see Table 49). A possible motivation for this special treatment is that this name is a syllable shorter than the other names (except Juppurla). ${ }^{19}$

The third exception is D1 Kapetye, which differs from both Arrernte and Anmatyerre Peltharre and from Alyawarr Apetyarre. Like Thangale, this name always begins with a consonant and consists of only three syllables instead of the four of most of the Kaytetye skin names (if the optional initial vowel is counted). A possible source is the Warlmanpa term Japaja, which likewise is a syllable shorter than expected (see the subsection 'Warlmanpa'). The initial consonant $k$ is unexpected, but otherwise it could be analysed as an adapted copy of Warlmanpa Japaja. A D1 form Kappiji is attested in Spencer and Gillen's Warumungu alongside Jappaljarri (see Table 49); however, the vowels are more easily explained if the direction of borrowing was from Warlmanpa to Kaytetye

18 Spencer and Gillen (1969a [1899]) is the only source that gives Purula for B1. This seems to be an Arrernte term that could be used in place of Pwerle. Later, Spencer and Gillen (1969b [1904], p. 98) stated that, in comparison to Arunta, Ilpirra and Iliaura, in the Kaitish and Unmatjera, Bulthara is replaced by Kabbadji and Purula by Opila'. Opila would represent *uperle, later pronounced as Pwerle. 19 It is not impossible that Thangale may be a reborrowing or updating that replaced an earlier *Angale. 
and thence to some subgroups of the Warumungu. ${ }^{20}$ Kaytetye Kapetye may have replaced an older form *Apetyarre, if, as we suggested, Alyawarr borrowed its form from Kaytetye. I suggest that this putative form would have been the normal outcome of borrowing from an earlier (and unattested) Warlmanpa form *apajjarri (with a double stop consonant) that developed via *Japatjarri from the original *Japaljarri (attested in Warlpiri). The lateral $l$ became a stop $t$ before another consonant in a number of other words in Warlmanpa.

\section{Neighbouring Languages}

This section gives the skin names in the neighbouring languages from which the Arandic languages have borrowed their terms. The Warlpiri terms were given in Table 43.

\section{Warumungu}

Table 49 presents the forms of the skin names given for 'Warramunga' by Spencer and Gillen (1969a [1899], p. 91) and Gillen (1968, p. 179), 'Warramunga, Walpari, and Wulmala' by Spencer and Gillen (1969b [1904], p. 100), as well as the modern representations by Simpson (2002, p. 30). Regarding spelling, note that a) $t j, c h$ and $d g$ are alternative ways of spelling the palatal sound; b) th (with a dental articulation) is the most typical pronunciation of the laminal stop in the old sources; c) the laminal stop (whether pronounced as dental or palatal) is represented by $j$ in the modern orthography; and d) the modern analysis recognises distinctive long consonants spelled with $p p$ and $k k$. The only substantive difference between the sources is in D1: during their stay with the Warumungu at Tennant Creek in 1901, Spencer and Gillen encountered both the terms Kabidgi and Tjapeltjeri for D1. The latter is given in their 1904 publication, but the former in the table of Gillen's diary, which also mentions Chapalcharrie (e.g. Gillen 1968, p. 178). Tjapeltjeri is the same as Warlpiri Japaljarri and Kabidgi is identical to Kapetye of the Kaytetye. It seems that both terms were in use-perhaps within different subgroups of the Warumungu. The main differences between Warumungu and Warlpiri masculine terms are a) the variant D1 Kappiji (as it would be spelled in the modern orthography) in place of Japaljarri;

20 I assume the (somewhat centralised) allophone of Warlmanpa /a/ was interpreted in Kaytetye as its central vowel /e/, which was then pronounced as [i] before the palatal ty and then copied by Warumungu as /i/. 
b) the shorter form Juppurla for B1 versus Warlpiri Jupurrurla; and c) the shorter form Jampin ${ }^{21}$ for D2 versus Warlpiri Jampijinpa. The last form probably originated as *Jampijin and results from the lenition of the $j$ to $y$ and subsequent reduction of $i y i$ to $i$. Note that there is no evidence for the final pa syllable that occurs in Warlpiri; it is known that $p a$ was a late addition to Warlpiri words that otherwise ended in a consonant (Hale 1973, pp. 452-5).

Table 49: Warumungu skin names according to sources.

\begin{tabular}{|c|c|c|c|}
\hline & Source & Masculine & Feminine \\
\hline A1 & $\begin{array}{l}\text { Spencer \& Gillen } 1899 \\
\text { Gillen } 1968 \\
\text { Spencer \& Gillen } 1904 \\
\text { Simpson } 2002\end{array}$ & $\begin{array}{l}\text { Thapanunga } \\
\text { Thapanunga } \\
\text { Thapanunga } \\
\text { Jappanangka }\end{array}$ & $\begin{array}{l}\text { Napanunga } \\
\text { Napanunga } \\
\text { Napanunga } \\
\text { Nappanangka }\end{array}$ \\
\hline A2 & $\begin{array}{l}\text { Spencer \& Gillen } 1899 \\
\text { Gillen } 1968 \\
\text { Spencer \& Gillen } 1904 \\
\text { Simpson } 2002\end{array}$ & $\begin{array}{l}\text { Chunguri } \\
\text { Chunguri } \\
\text { Tjunguri } \\
\text { Jungarrayi }\end{array}$ & $\begin{array}{l}\text { Namagili } \\
\text { Namagillie } \\
\text { Namigilli } \\
\text { Namikili }\end{array}$ \\
\hline D1 & $\begin{array}{l}\text { Spencer \& Gillen } 1899 \\
\text { Gillen } 1968 \\
\text { Spencer \& Gillen } 1904 \\
\text { Simpson } 2002\end{array}$ & $\begin{array}{l}\text { Kabidgi } \\
\text { Kabidgi } \\
\text { Tjapeltjeri } \\
\text { Jappaljarri }\end{array}$ & $\begin{array}{l}\text { Nalchari } \\
\text { Nalcharrie } \\
\text { Naltjeri } \\
\text { Naljarri }\end{array}$ \\
\hline D2 & $\begin{array}{l}\text { Spencer \& Gillen } 1899 \\
\text { Gillen } 1968 \\
\text { Spencer \& Gillen } 1904 \\
\text { Simpson } 2002\end{array}$ & $\begin{array}{l}\text { Thapungerta } \\
\text { Thapungartie } \\
\text { Thapungarti } \\
\text { Jappangarti }\end{array}$ & $\begin{array}{l}\text { Napungerta } \\
\text { Napungartie } \\
\text { Napungerta } \\
\text { Nappangarti }\end{array}$ \\
\hline B1 & $\begin{array}{l}\text { Spencer \& Gillen } 1899 \\
\text { Gillen } 1968 \\
\text { Spencer \& Gillen } 1904 \\
\text { Simpson } 2002\end{array}$ & $\begin{array}{l}\text { Chupilla } \\
\text { Chupilla } \\
\text { Tjupila } \\
\text { Juppurla }\end{array}$ & $\begin{array}{l}\text { Naralu } \\
\text { Naralu } \\
\text { Naralu } \\
\text { Narrurlu }\end{array}$ \\
\hline B2 & $\begin{array}{l}\text { Spencer \& Gillen } 1899 \\
\text { Gillen } 1968 \\
\text { Spencer \& Gillen } 1904 \\
\text { Simpson } 2002\end{array}$ & $\begin{array}{l}\text { Thungalli } \\
\text { Thungalli } \\
\text { Thungalla } \\
\text { Jangali }\end{array}$ & $\begin{array}{l}\text { Nungalli } \\
\text { Nungalli } \\
\text { Nungalla } \\
\text { Nangali }\end{array}$ \\
\hline C1 & $\begin{array}{l}\text { Spencer \& Gillen } 1899 \\
\text { Gillen } 1968 \\
\text { Spencer \& Gillen } 1904 \\
\text { Simpson } 2002\end{array}$ & $\begin{array}{l}\text { Thakomara } \\
\text { Thakomara } \\
\text { Thakomara } \\
\text { Jakkamarra }\end{array}$ & $\begin{array}{l}\text { Nakomara } \\
\text { Nakomara } \\
\text { Nakomara } \\
\text { Nakkamarra }\end{array}$ \\
\hline C2 & $\begin{array}{l}\text { Spencer \& Gillen } 1899 \\
\text { Gillen } 1968 \\
\text { Spencer \& Gillen } 1904 \\
\text { Simpson } 2002\end{array}$ & $\begin{array}{l}\text { Chambein } \\
\text { Chambein } \\
\text { Tjambin } \\
\text { Jampin }\end{array}$ & $\begin{array}{l}\text { Lambein } \\
\text { Lambein } \\
\text { Nambin } \\
\text { Nampin }\end{array}$ \\
\hline
\end{tabular}

Source: Gillen (1968, p. 179), Simpson (2002, p. 30) and Spencer and Gillen (1899, p. 91; 1904, p. 100).

21 The form Lambein seems to be an error; the text of Gillen's (1968, p. 230) diary gives Nambein instead, which agrees with the form given in their second volume. 


\section{Warlmanpa}

While based at Tennant Creek in 1901, Spencer and Gillen also met with people belonging to the "Wolmalla Tribe ... which occupies a tract of country adjoining the Warramunga south western boundary' (Gillen 1968, p. 251). They are said to be intermarried with the Warumungu and to share their system of organisation. Spencer and Gillen witnessed their ceremonies associated with a site called Tchalyirpa [Jalyirrpa], whose owners appeared to belong to the Kabidgi and Chunguri classes (Gillen 1968, p. 254). This group can be identified with the Warlmanpa of the Kanturrpa estate (Aboriginal Land Commissioner 1991, p. 19). ${ }^{22}$ Spencer and Gillen (1969b [1904], p. 100) gave a unified listing of skin names for 'Warramunga, Walpari, and Wulmala' (see Table 49). They also met some members of the 'Walpari Tribe', described as adjoining the western border of the Warumungu and extending a long way to the south and west (Gillen 1968, p. 251), whose 'totemic system etc. is on all fours with the Warramunga' (p. 258). Spencer and Gillen (1969a [1899], p. 91) had earlier published a skin name list attributed to the 'Walpari tribe', which must have been obtained before the 1901 trip, presumably through Gillen's contacts with the Tennant Creek Telegraph Station. A comparison of this list with the modern Warlmanpa terms recorded by Nash (1979) shows that they are virtually identical (see Table 50); in fact: 'their equivalence with the modern Warlmanpa terms (as opposed to modern Warlpiri subsection names) is part of the evidence that Spencer and Gillen's "Walpari" at Tennant Creek were probably speakers of Warlmanpa' (Nash 2015).

Table 50: Warlmanpa skin names.

\begin{tabular}{|l|l|l|l|}
\hline & Source & Masculine & Feminine \\
\hline A1 & $\begin{array}{l}\text { Spencer \& Gillen 1899 } \\
\text { Nash 1979 }\end{array}$ & $\begin{array}{l}\text { Chapanunga } \\
\text { Japanangka }\end{array}$ & $\begin{array}{l}\text { Napanunga } \\
\text { Napanangka }\end{array}$ \\
\hline A2 & $\begin{array}{l}\text { Spencer \& Gillen } \\
\text { Nash }\end{array}$ & $\begin{array}{l}\text { Chunguri } \\
\text { Jungurra }\end{array}$ & $\begin{array}{l}\text { Namilpa } \\
\text { Namurlpa }\end{array}$ \\
\hline D1 & $\begin{array}{l}\text { Spencer \& Gillen } \\
\text { Nash }\end{array}$ & $\begin{array}{l}\text { Chapatcha } \\
\text { Japaja }\end{array}$ & $\begin{array}{l}\text { Napatcha } \\
\text { Napaja }\end{array}$ \\
\hline D2 & $\begin{array}{l}\text { Spencer \& Gillen } \\
\text { Nash }\end{array}$ & $\begin{array}{l}\text { Chapungarta } \\
\text { Japangarti }\end{array}$ & $\begin{array}{l}\text { Napungarta } \\
\text { Napangarti }\end{array}$ \\
\hline
\end{tabular}

22 'There seemed to be a consensus that the site Jalyirrpa belongs to Kanturrpa: it lies just beyond the western limits of Warumungu country, where Warlpiri and Warumungu people are to some extent mixed' (Aboriginal Land Commissioner 1991). Cf. the comment (p. 26): 'Kanturrpa is the name of a group of Warlmanpa or Warlpiri people'. 


\begin{tabular}{|l|l|l|l|}
\hline & Source & Masculine & Feminine \\
\hline B1 & $\begin{array}{l}\text { Spencer \& Gillen } \\
\text { Nash }\end{array}$ & $\begin{array}{l}\text { Chupilla } \\
\text { Jupula }\end{array}$ & $\begin{array}{l}\text { Napula } \\
\text { Napula }\end{array}$ \\
\hline B2 & $\begin{array}{l}\text { Spencer \& Gillen } \\
\text { Nash }\end{array}$ & $\begin{array}{l}\text { Chungalla } \\
\text { Jangala }\end{array}$ & $\begin{array}{l}\text { Nungalla } \\
\text { Nangala }\end{array}$ \\
\hline C1 & $\begin{array}{l}\text { Spencer \& Gillen } \\
\text { Nash }\end{array}$ & $\begin{array}{l}\text { Chakuma } \\
\text { Jakama }\end{array}$ & $\begin{array}{l}\text { Nakuma } \\
\text { Nakama }\end{array}$ \\
\hline C2 & $\begin{array}{l}\text { Spencer \& Gillen } \\
\text { Nash }\end{array}$ & $\begin{array}{l}\text { Champechinpa } \\
\text { Jampijinpa }\end{array}$ & $\begin{array}{l}\text { Nambechinpa } \\
\text { Nampijinpa }\end{array}$ \\
\hline
\end{tabular}

Source: Nash (1979) and Spencer and Gillen (1899, p. 91).

\section{Comparison of Forms between the Northern Languages}

The forms of the skin names in the three northern languages are sufficiently similar (with the exceptions noted in the next paragraph) to point to a common original set of terms that were borrowed into each of these languages. Nevertheless, the few differences between the languages help to identify the sources of the Arandic terms. The Warlpiri terms are considered closest to the original form (cf. McConvell 1985, p. 4): the only changes they have undergone are the replacement of $r t$ by $r d$ (a retroflex flap) in D2 Japangardi and the addition of pa to the end of C2 *Jampijin. The last change is shared with Warlmanpa, whereas Warumungu preserve a form with final $n$. Warlmanpa and Warumungu both have shorter forms for B1, Jupula and Juppurla respectively, that lack the third syllable of Warlpiri Jupurrurla. Three Warlmanpa terms lack the fourth syllable found in the other languages: Jungurra(yi), Jakama(rra) and Japa(l)ja(rri). Further, D1 Japaja lacks the l of Japaljarri; I assume that this reflects a sound change whereby a lateral sound became a stop before another stop, as in jitpitpi 'Eucalyptus setosa' versus Warlpiri jilpilpi, purtku 'warm' versus Warlpiri purlku, and jurtatja 'members of wife's patriline' versus Warlpiri jurdalja. An inherited Japaljarri would have become Japatjarri, which we must assume simplified to Japajarri. This form would be the basis for the loan word Apetyarre found in Alyawarr and hypothesised to have been once present in Kaytetye. The dropping of the final syllable of Japajarril Napajarri, Jakamarral Nakamarra, and Jungurrayi would have taken place after Japajarri was borrowed in Kaytetye (as Apetyarre).

The feminine forms in the northern languages generally correspond to the masculine forms, albeit with initial $n$ in place of the $j$ of the masculine terms - with the following exceptions: a) for B1, the vowels of the first 
syllable differ for Warlpiri Napurrurla versus Jupurrurla, Warumungu Narrurlu versus Juppurla and Warlmanpa Napula versus Jupula; b) for D1, Warumungu Naljarri shows a shortened form versus Jappaljarri, and is radically unlike the alternative Warumungu form Kappiji; and c) for A2, Warumungu and Warlmanpa have feminine forms Namikili and Namurlpa that do not match the respective masculines Jungarrayi and Jungurra.

\section{Different Sources for Different Arandic Languages}

All Anmatyerre forms can be explained in terms of a Warlpiri source, provided that D1 was borrowed before pa became fixed on Jampijinpa. The B1 form of Kaytetye and Alyawarr, whose earliest Arandic form would have been * uperle, must come from Warumungu (or possibly Warlmanpa, which lacks the retroflexed $r l$ ); further, the Arandic form must be based on the masculine Jupurlu, since the feminine form, with a different vowel in the first syllable, would rather have yielded *Arrwerle. The Alyawarr C form Apetyarre can be traced to a Warlmanpa *Japatjarri, resulting from an earlier Japaljarri and preceding the more recent Japaja. It is assumed that this form was transmitted by the intervening Kaytetye, where an earlier ${ }^{*}$ Apetyarre was later replaced by Kapetye. Note that the $j$ from the middle of *apajarri was copied as Alyawarr ty, whereas the form of Japaljarri copied by Anmatyerre resulted in Arandic th (in *Apeltharre). The Kaytetye D1 form Kapetye is interpreted as an updated version of *Apetyarre-reborrowed or remodelled after Warlmanpa shortened its *apatjarri to Japaja. It is not known why the word-initial $j$ was adapted as $k$ for this term rather than being truncated as in the other terms, except for Thangale. It is hypothesised that Kappiji was borrowed from Kaytetye into some subgroups of the Warumungu. Finally, the B2 form Thangale of Katyetye, recorded also for Spencer and Gillen's 'Unmatjira' and 'Iliaura', could have been borrowed from Jangala in any of the three languages; preference can possibly be given to Warumungu as the source, on the basis that Spencer and Gillen more frequently rendered initial $j$ as th (rather than $t j$ or $c h$ ) before the vowel /a/ for this language-presumably because they heard the Warumungu laminal stop as more dental than palatal in articulation. It is possible that Kaytetye Thangale represents an updating of an earlier ${ }^{*}$ Angale, which is the presumed earliest form in the other Arandic languages. ${ }^{23}$ Table 51 summarises the possible sources of the

23 An alternative scenario in which Kaytetye only borrowed the term Thangale later than the rest of the set 2 terms hardly seems realistic. 
Arandic skin names, each of which is given in its presumed earliest form, including initial vowels that were subsequently lost in some dialects. The languages and their abbreviations are Lower Arrernte (LA); (Western, Central and Eastern) Arrernte (Ar), Anmatyerre (An), Kaytetye (K), Alyawarr (Al), Warlpiri (Wlp), Warlmanpa (Wmp) and Warumungu (Wru). The section 'Borrowing, Sound Change and Relative Chronology' describes the phonology of the Arandic forms in more detail.

Table 51: Sources of Arandic skin names.

\begin{tabular}{|l|l|l|l|c|c|c|c|}
\hline & Source language & Form & LA & Ar/An & K & Al \\
\hline A1 & Wip/Wmp/Wru & Japanangka & Apenangke & $\sqrt{ }$ & $\sqrt{ }$ & $\sqrt{ }$ & \\
\hline A2 & Wip/Wmp/Wru & Jungarrayi & Kngwarreye & & $\sqrt{ }$ & $\sqrt{ }$ & $\sqrt{ }$ \\
\hline B1 & Wip & Jupurrurla & Uperrurle & $\sqrt{ }$ & $\sqrt{ }$ & & \\
\hline B1 & Wmp/Wru & Jupurla & Uperle & & & $\sqrt{ }$ & $\sqrt{ }$ \\
\hline B2 & Wip/Wmp/Wru & Jangala & Angale & & $\sqrt{ }$ & & \\
\hline B2 & Wip, Wmp, Wru & Jangala & Thangale & & & $\sqrt{ }$ & \\
\hline C1 & Wip/Wmp/Wru & Jakamarra & Akemarre & $\sqrt{ }$ & $\sqrt{ }$ & $\sqrt{ }$ & $\sqrt{ }$ \\
\hline C2 & Wip/Wmp & Jampijin & Ampetyane & & $\sqrt{ }$ & $\sqrt{ }$ & \\
\hline D1 & Wip/Wru & Japaljarri & Apeltharre & $\sqrt{ }$ & $\sqrt{ }$ & & \\
\hline D1 & Wmp & Japajarri & Apetyarre & & & & $\sqrt{ }$ \\
\hline D1 & Wmp & Japaji & Kapetye & & & $\sqrt{ }$ & \\
\hline D2 & Wip/Wmp/Wru & Japangardi & Apengarte & & $\sqrt{ }$ & $\sqrt{ }$ & \\
\hline
\end{tabular}

Source: Author's work.

\section{Borrowing, Sound Change and Relative Chronology}

\section{Arandic Phonology, Sound Change and Borrowing Patterns}

The Arandic languages differ in their phonology from the norms found in the languages to the north and west from which they have presumably obtained their skin names. While words in other languages typically begin with a consonant, Arandic words may begin with a vowel. 
While other languages use only the vowels $a, i$ and $u$, Arandic languages make sparing use of $i$ and $u$ but heavily use a central vowel (as in English the) that is spelled $e$. Arandic languages also have a set of rounded consonants, spelled $C w$ (where $C$ is a consonant); $e$ after a rounded consonant sounds like $u$ in other languages.

The distinctive phonological structure of the Arandic languages results from a series of phonological changes (or sound changes) that occurred during the history of these languages. These changes are described and justified in Koch (1997b) and summarised in Koch (2004). Koch (2007) added a few details about how Kaytetye and the rest of the Arandic languages developed differently with respect to words beginning with $C y a-, C y u$ - and wi- (where Cy stands for any palatal consonant). If the skin names were borrowed into the Arandic languages, as everyone agrees they were, the question arises as to when this borrowing occurred relative to the distinctive Arandic sound changes—in particular: 'initial dropping'. The relevance of these changes to the borrowing of skin names was highlighted by McConvell (1985, p. 6).

As a consequence of the Arandic sound changes and later borrowing patterns, we can distinguish three chronological phases of Arandic languages, which have resulted in three separate strata of Arandic vocabulary. Examples are shown in Table 52 (here, as elsewhere, * marks forms that are unattested but reconstructed). These lexical sets have different characteristics with regard to the treatment of (non-final) vowels and initial consonants. In all three sets, final vowels are always $e$ (= shwa). ${ }^{24}$ Word-internal vowels are treated differently: in stratum I, all vowels except those in the first syllable are changed to $e$; in strata II and III, non-final vowels largely preserve their quality- $i$ is copied as $e, a$ as $a$ but as $e$ in the second syllable of four-syllable words (where it reflects a higher allophone in the source language), and $u$ as either $u$ or $w e$, which is interpreted as a rounded variant of $e$ that is conditioned by rounding on the preceding consonant. The initial consonant is deleted in all words of strata I and II, but is retained in stratum III. I have interpreted vocabulary in stratum II as the result of a borrowing pattern that copies vowels (except final ones) faithfully but truncates the initial consonant (Koch 1997a, 2014). This pattern was facilitated by the existence of many pairs of words

24 In the analysis by Breen and Pensalfini (1999), they argued that the final vowel is absent from the phonological representation of words. This analysis is reflected in the orthographies of Alyawarr and Anmatyerre, where final vowels are not written. 
that displayed this same pattern-some being old inherited cognates but others resulting from the Warlpiri borrowing of Arandic vowel-initial words and adding an initial consonant $(y, w$ or $n g)$ to fit them to Warlpiri phonotactics, which requires an initial consonant (see Koch 2014).

Table 52: Examples of words in the three lexical strata.

\begin{tabular}{|l|l|l|l|l|}
\hline & & Source & Outcome & Gloss \\
\hline I & $\begin{array}{l}\text { Inherited words that have } \\
\text { undergone sound change }\end{array}$ & $\begin{array}{l}\text { kaparli } \\
\text { ngumparna } \\
\text { kurrparu } \\
\text { kayirra } \\
\text { pankuIV }\end{array}$ & $\begin{array}{l}\text { aperle } \\
\text { *umperne } \\
\text { *urrpere } \\
\text { ayerre[re] } \\
\text { ankele }\end{array}$ & $\begin{array}{l}\text { father's mother } \\
\text { wife's brother } \\
\text { magpie } \\
\text { north } \\
\text { cousin }\end{array}$ \\
\hline II & $\begin{array}{l}\text { Loan words adapted with } \\
\text { truncation }\end{array}$ & $\begin{array}{l}\text { jurdalja } \\
\text { kangkuru } \\
\text { mingkurlpa } \\
\text { marliyarra }\end{array}$ & $\begin{array}{l}\text { urtaltye } \\
\text { angkwere } \\
\text { (i)ngkwerlpe } \\
\text { arleyarre }\end{array}$ & $\begin{array}{l}\text { wife's mother } \\
\text { elder sister } \\
\text { native tobacco } \\
\text { initiate }\end{array}$ \\
& Loan words adapted & $\begin{array}{l}\text { majardi } \\
\text { japirnpa } \\
\text { janyungu } \\
\text { kajalarra } \\
\text { marrrapirnti } \\
\text { wanapari }\end{array}$ & $\begin{array}{l}\text { matyarte } \\
\text { tyapernpe } \\
\text { tyanywenge } \\
\text { katyelarre } \\
\text { marrepernte } \\
\text { wanapare }\end{array}$ & $\begin{array}{l}\text { pubic tassel } \\
\text { boil, sore } \\
\text { tobacco } \\
\text { fruit pick } \\
\text { nose-bone } \\
\text { dingo }\end{array}$ \\
\hline
\end{tabular}

Source: Koch (2014).

\section{Skin Names and Lexical Strata}

I have claimed that the Arandic skin names of both sets 1 and 2 belong to stratum II-that is, their lack of an initial consonant is explicable by the pattern of borrowing with truncation (Koch 2014). However, the junior skin names of Anmatyerre and Kaytetye belong to stratum III and represent loan words that follow a more recent pattern of adaptation that does not involve consonant truncation (see subsection 'Late Borrowing of Junior Skin Names').

McConvell's solution basically posits that skin names were borrowed before the Arandic sound change that deleted initial consonants ceased to operate-which would place them in my stratum I. Table 53 shows the expected fate of the set 1 skin names if they had been borrowed before the operation of all presumed Arandic sound changes: these are set alongside the Warlpiri originals and the attested Arandic forms. Note that in this hypothetical stratum I scenario, all the vowels except those in the first syllable would become $e$. Further, the $n g k$ cluster would lose its stop (see Koch 1997b). However, the actual vowel adaptation patterns are 
identical to those of stratum III, which are clearly loan words postdating the sound changes, and to stratum II, which we claim also represent adapted loan words postdating the sound changes. The (adult) skin names clearly do not belong to stratum III, since they do not preserve the initial consonant. If they belonged to stratum III, they would look like the forms in the rightmost column of Table 53. We know this from the fact that the Anmatyerre dictionary (Green 2010) gives the Warlpiri names as they are used by Anmatyerre people today. Table 54 gives the Anmatyerre versions of the masculine and feminine Warlpiri (adult) skin names. (Note that the Anmatyerre spelling system does not represent final vowels.)

Table 53: Hypothetic developments of skin names if borrowed early.

\begin{tabular}{|l|l|l|l|l|}
\hline & Warlpiri source & Hypothetical Arandic I & Actual Arandic & Arandic III \\
\hline A1 & Japanangka & Apenenge & Apanangke & Tyapenangke \\
\hline C1 & Jakamarra & Akemerre & Akemarre & Tyakemarre \\
\hline D1 & Japaljarri & Apeltherre & Apeltharre & Tyapeltyarre \\
\hline B1 & Jupurrurla & Uperrerle & Uperrurle? & Tyweperrerle \\
\hline
\end{tabular}

Source: Author's work.

Table 54: Warlpiri adult skin names as used by the Anmatyerre.

\begin{tabular}{|c|c|c|}
\hline & Warlpiri & Anmatyerre (stratum III) \\
\hline A1 & $\begin{array}{l}\text { Japanangka } \\
\text { Napanangka }\end{array}$ & $\begin{array}{l}\text { Tyapenangk } \\
\text { Napenangk }\end{array}$ \\
\hline A2 & $\begin{array}{l}\text { Jungarrayi } \\
\text { Nungarrayi }\end{array}$ & $\begin{array}{l}\text { Tywengarray } \\
\text { Nwengarray }\end{array}$ \\
\hline B1 & $\begin{array}{l}\text { Jupurrurla } \\
\text { Napurrurla }\end{array}$ & $\begin{array}{l}\text { Tyweperrerl } \\
\text { Napwerrerl }\end{array}$ \\
\hline B2 & $\begin{array}{l}\text { Jangala } \\
\text { Nangala }\end{array}$ & $\begin{array}{l}\text { Tyangal } \\
\text { Nangal }\end{array}$ \\
\hline C1 & $\begin{array}{l}\text { Jakamarra } \\
\text { Nakemarr }\end{array}$ & $\begin{array}{l}\text { Tyakemarr } \\
\text { Nakemarr }\end{array}$ \\
\hline C2 & $\begin{array}{l}\text { Jampiijinpa } \\
\text { Nampijinpa }\end{array}$ & $\begin{array}{l}\text { Tyampetyenp } \\
\text { Nampetyenp }\end{array}$ \\
\hline D1 & $\begin{array}{l}\text { Japaljarri } \\
\text { Napaljarri }\end{array}$ & $\begin{array}{l}\text { Tyapeltyarr } \\
\text { Napeltyarr }\end{array}$ \\
\hline D2 & $\begin{array}{l}\text { Japangardi } \\
\text { Napangardi }\end{array}$ & $\begin{array}{l}\text { Tyapengart } \\
\text { Napengart }\end{array}$ \\
\hline
\end{tabular}

Source: Green (2010). 
McConvell claimed that two pieces of evidence indicate that sets 1 and 2 entered the Arandic languages in separate chronological phases. McConvell (1985, p. 23; 1996, p. 131) cited the different treatment of Warlpiri $j$ in the earlier borrowed Peltharre (from Japaljarri) and the more recently adopted Mpetyane (from *Jampijin) as evidence for chronologically different sound changes. However, this difference can be interpreted as the consequence of the fact that the Warlpiri laminal consonant $j$ corresponds to two separate Arandic consonants-a lamino-dental th and a laminopalatal ty. Warlpiri $j$ had a palatal allophone before the $i$ of ${ }^{*} J a m p i j i n$, which was naturally reproduced as ty in the Arandic languages, while the normal allophone that occurred before $a$ in Japaljarri was reproduced as the dental th. There is no need to assume different chronological strata. Further, the penultimate vowel of Arandic (a)mpetyane versus Warlpiri Jampijinpa needs explaining. I have made the following suggestions: the Warlpiri source was *Jampijin (before the final syllable $p a$ became a fixed part of the stem); the final vowel was added because it was required by Arandic phonotactics; and a form borrowed and adapted as *ampetyene had its third vowel altered to $a$ to fit the pattern of other skin names, which had a vowel pattern $a-e-a-e$ (Koch 2014).

A stronger argument for making a chronological distinction between sets 1 and 2 is made by McConvell from the differential treatment of initial vowels in the skin names. He observed that in Spencer and Gillen's list of Arrernte and 'Ilpirra' [= Anmatyerre] skin names, all the set 2 terms begin with a vowel but those of set 1 with a consonant. While recognising that this is no longer the situation in current Arandic languages, ${ }^{25}$ he concluded that 'the earlier transcription seems too systematic to be an error on Spencer and Gillen's part' (McConvell 1985, p. 23). However, it is not clear that this difference is phonologically significant for two reasons. First, the skin name lists given by other scholars do not differentiate between sets 1 and 2. It can be seen from Table 46 that forms quoted by Schulze, Strehlow and the modern Western Arrernte dictionaryall reflecting Western Arrernte-and Mathews's Harts Range Arrernte all involve initial consonants in set 2 , as well as set 1 terms. Further, initial vowels are found in set 1 skin names in Kaytetye and Spencer and Gillen's Iliaura (see Table 47); hence, a solution that might conceivably work for Arrernte will not account for all Arandic languages. A second reason to

25 Although McConvell (1985, p. 23) stated that 'no Aranda subsection terms have the initial vowel in the commonly used forms today', initial vowels are used in Wilkins's (1989, p. 35) B2 Angale and in Henderson and Dobson's (1994) B2 Angale and C2 Ampetyane (see Table 46). 
doubt the significance of initial vowels in the skin names comes from the well-known variability of initial vowels in Arandic languages. Stirling (1896, p. 10) already commented on the uncertainty of whether final and initial vowels were present in Arrernte words. Green (2010, p. 744) noted that 'many words in Arandic languages may be pronounced either with or without the initial $a$ vowel'. Wilkins (1989, pp. 81-2), for the Mparntwe (Alice Springs) dialect of Arrernte, agonised over the proper representation of the large number of words that might be pronounced either with an initial consonant or with an initial vowel $a$. Breen (2001, p. 65) described the 'comparative absence of initial vowels, especially /a/' from Western Arrernte. Thus, it seems to me that the skin names of sets 1 and 2 were all borrowed into Anmatyerre with an initial vowel, which was variably pronounced, and when further borrowed into Western Arrernte, the vowel was characteristically omitted - as well as in Lower Arrernte, which would have received the terms via Western Arrernte. I suggest that Spencer and Gillen did not so much make an error as simply standardise variable forms in a way that could imply a patterned distinction. ${ }^{26}$

McConvell's (1985, pp. 6, 23; 1996, p. 130-2) discussion of Arandic skin names posited two separate borrowing strata for sets 1 and 2, with both preceding a stratum (our III) that does not involve consonant deletion. However, both of these earlier strata are assumed to involve the historical Arandic sound changes of 'initial dropping' - the first deleting the beginning consonant and vowel (changing Japanangka to Penangke) and the second deleting only the first consonant (changing Japangardi to Apengarte). According to McConvell's conception (clarified by personal communication of 31 August 2014), the set 1 forms were borrowed, then underwent the sound change $\# \mathrm{C}_{1}>\varnothing$ (deletion of first consonant of the word) and then the change $\# \mathrm{~V}_{1}>\varnothing$ (deletion of first vowel of the word). At a later stage, set 2 forms were borrowed and underwent the change $\# \mathrm{C}_{1}>$ $\varnothing$, but not $\# \mathrm{~V}_{1}>\varnothing$. This scenario requires the persistence of the first sound change - that the 'sound change of initial dropping ... was still operative up until the mid-nineteenth century' (McConvell 1996, p. 130)—but not that of the second change. In my view, this solution raises problems

26 I imagine a scenario as follows. Gillen (who had worked at telegraph stations in Lower Arrernte and then Central Arrernte territory) first learned the four section names from the Lower Arrernte, who omitted the initial vowel. When he later became familiar with the Central Arrernte terms, which had a variable vowel, he assumed they were the same as the forms he already knew from Lower Arrernte. He first learned of the second set of terms from the Anmatyerre, who characteristically pronounced the initial vowel. Then, when he realised the same terms were also being used among the Central Arrernte, he assumed they were vowel-initial like the Anmatyerre forms, although they were in fact variable. 
of both relative chronology—consonant deletion applies both before and after vowel deletion - and the duration of a sound change. ${ }^{27}$ How can a sound change persist after it has altered all the candidate phonemes? The only input to the change would be words borrowed after the change first operated. At best, the 'change' would exist merely as a constraint, motivated by the absence of word-initial consonants. However, why would it continue after the deletion of initial vowels again allowed words to begin with a consonant (i.e. after Apenangke had changed to Penangke)? It seems to me that the only way the persistence of such a sound change can be interpreted is in terms of the adaptation of loan words, so that their resulting form is like that resulting from the original sound change. This makes McConvell's solution for set 2 skin names equivalent to mine. One can then ask whether set 1 skin names could not have been treated the same way, and been borrowed after the consonant-deletion change had already taken place- that is, in my stratum II.

Thus, according to my interpretation, the chronology of borrowing and sound changes is as follows. After the major Arandic sound changes had taken place (in stratum I), there was a pattern of borrowing (from Warlpiri and other languages with initial consonants) that involved the truncation of the first consonant (stratum II). In Western Arrernte, in particular, there was a subsequent change that eliminated the resulting initial vowel, especially if it was $a$. At some time, around or before the mid-nineteenth century, a second set of skin names was borrowed by Anmatyerre and Kaytetye; these were also adapted by the deletion of the first consonant (still according to stratum II processes). When passed on to western and Central Arrernte, these new terms were treated just like the pre-existing set 1 skin names, which involved dropping the first vowel, at least in Western Arrernte. Consequently, Warlpiri Japangardi, which was borrowed into Anmatyerre as Apengarte, was further adapted as Pengarte, and so on.

\section{Late Borrowing of Junior Skin Names}

There were some skin names that were borrowed according to the recent pattern of Arandic borrowing, which preserved intact the initial consonant (our stratum III). These are the junior skin names found in Kaytetye and western dialects of Anmatyerre. Formally, the junior terms are almost

27 Recent theoretical work on sound change suggests that their period of operation is typically of rather short duration (e.g. Janda \& Joseph 2003). 
identical to their Warlpiri counterparts—allowing for the differences in phoneme systems and orthographies. ${ }^{28}$ Their formal similarity can be seen in Table 55, which presents the male and female terms of Warlpiri, Kaytetye and Western Anmatyerre (the latter is based on Green 1998, p. 105; 2010). Obviously, the junior terms are later borrowings than the adult terms. ${ }^{29}$

Table 55: Junior skin names in Warlpiri, Kaytetye and Western Anmatyerre.

\begin{tabular}{|l|l|l|l|}
\hline & & M & F \\
\hline A1 & Wlp & Janama & Ngamana, Nangka \\
& Kay & Tyaname & Ngamane \\
& WAnm & Tyanam & Ngaman \\
\hline A2 & Wip & Jukurdayi & Ngapita, Ngampukulu \\
& Kay & Tywekertaye & Ngapet, Ngampekwerl \\
& WAnm & Tywekertay & Ngampurla, Ngapurru \\
\hline B1 & Wip & Jurlama, Jupurru & Ngamperle \\
& Kay & Tywerlame & Ngamp(w)erl, Napwerr \\
& WAnm & Tywerlam, Tyweperr & Ngangkala, Nangali \\
\hline B2 & Wip & Jangkarli & Ngangkale \\
& Kay & Tyangkarle & Ngangkal, Nangaley \\
& WAnm & Tyangkarl & Wajala, Nakakutu, Nakarra \\
\hline C1 & Wip & Jakarra & Watyale \\
& Kay & Tyakarre & Watyal, Nakakwet, Nakarr \\
& WAnm & Tyakarr & Ngampijakurdu, Nampit \\
\hline C2 & Wip & Jampirlka, Jampit & Mpetyakwerte \\
& Kay & Tyamperlke & Mpetyakwert, Ngampin \\
& WAnm & Tyamperlk & Ngalyirri \\
\hline D1 & Wip & Japalya & Ngalyerre \\
& Kay & Tyapalyerr \\
& WAnm & Tyapaly & Ngampayardi, \\
\hline D2 & Wip & Japayardi, Jangari & Ngampeyarte, \\
& Kay & Tyapeyarte & Tgampeyart, Ngampart \\
& WAnm & Tyapeyart, Tyapart ${ }^{1}$ & \\
\hline
\end{tabular}

Source: Laughren (1982, p. 76); Turpin and Ross (2012, pp. 809-10); Green (2010, p. 744).

1 Tyapart versus Tyapeyart and Ngampart versus Ngampeyart reflect language-internal reduction of the sequence eya.

28 These names are identical to adult names found in languages further to the north, such as Gurindji and Jingulu.

29 Meggitt (1962, p. 165) implied that the Warlpiri junior terms were used only among the eastern Warlpiri then living at Philip Creek, and suggested, improbably, that these were 'probably borrowed from the Yanmadjari [Anmatyerre] tribe'. 
In addition to the junior skin names, there are two examples of the retention of initial consonants in adult skin names. The B2 form Thangale, comparable to Warlpiri Jangala, is found in Kaytetye, as well as in Spencer and Gillen's Anmatyerre and Alyawarr. This may represent a late updating of an earlier *Angale - for which I cannot offer any motivation. Likewise, the Kaytetye D1 term Kapetye may represent an updating of an earlier *Apetyarre (which is found in Alyawarr) under the influence of Warlmanpa *Japaji-with an unexplained substitution of $k$ for initial $j$.

\section{Social Aspects of the Adoption of New Social Categories}

\section{Native Traditions on the Origin of Skins}

Spencer and Gillen attempted to obtain Indigenous accounts of the origin of the social categories. As might be expected, Aboriginal people gave explanations in terms of the activities of Dreaming characters. For example, Gillen's diary for 3 July 1901 records a Kaytetye tradition ${ }^{30}$ according to which the Moon man Arilpa [Arelpe] assigned marriage classes to people:

Men of all classes visited Arilpa who furnished each man with a wife of the proper class and explained to them the awful enormity of marriage outside of the proper class ... It was from the great Arilpa that the Kaitish people - so says the tradition-learnt the proper class into which each of the 8 divisions was to intermarry. (Gillen 1968, p. 154)

Such accounts did not satisfy Spencer and Gillen's quest for historical answers:

How on earth this class system arose in these Central Tribes is a mystery into which we have probed deeply without a shade of success. The blacks do not appear to have any tradition as to its origin. (Gillen 1968, p. 155)

We have been quite unable to discover the meaning of these names in any of the central tribes, or to obtain the slightest clue as to their origin, which must date very far back. (Spencer \& Gillen 1969b [1904], p. 98)

30 For a similar Warumungu tradition, see Spencer and Gillen (1969b [1904], p. 429).

31 See Spencer and Gillen (1969b [1904], p. 412) for another version of this story. The Moon man is associated with a place called Karla karlu. I believe this refers to a site around the Devils Marbles, on the boundary between the Kaytetye and Warumungu lands. This is consistent with the likely northern source of skin names borrowed into Kaytetye. Another Kaytetye myth about the Moon man, given in Koch (1993, pp. 4-10), also has the Moon man coming from the north, from Warumungu country. 
Some of the myths involved the mention of the skin names of participants. While Anmatyerre, Kaytetye and Warumungu stories mention the subsections of the Dreamings, it appears that the Arrernte myths presented in Spencer and Gillen (1927, 1969a [1899]) only attribute the four section names to Dreamings. This may be significant, given that Kaytetye and Anmatyerre had the eight-term system earlier than did the Arrernte; the Arrernte adoption of the second set of names was probably too recent for these names to have become fully integrated into their mythology.

Spencer and Gillen claimed to discern four or five chronological layers of the Dreamtime from Arrernte accounts. This is best summarised in Spencer and Gillen (1927, p. 322). In the first period, the supernatural Dreamings formed human beings, each of whom implicitly belonged to the particular totem (plant or animal) out of which they were formed. In the next stage, Ullagubbera [alekapere] (little hawk) men introduced the use of circumcision by means of stone knives (instead of firesticks) and assigned the four section names, but without respect to any marriage regulations. Achilpa [atyelpe] (wild cat) men then introduced the rite of subincision and the more advanced engwura [angkwerre] initiation ceremony. Later, a number of people of the Emu clan first introduced marriage regulations whereby Penangke must marry Perrurle and Peltharre must marry Kemarre, but allowing that a person could marry someone classified as either anua [anewe] or unkulla [ankele] — that is, second or first cross-cousin. A subsequent reform followed an assembly of a number of groups of Emu people, held at Urliipma and then at Apaura, both in the southern part of the territory of the Ilpirra [Anmatyerre], north of the MacDonnell Ranges. Here, it was decided that marriage was to be restricted to people related as anua [anewe]. After an engwura [angkwerre] ceremony was performed, 'the people stood up, each man with his wife or wives behind him, and those who were wrongly united were separated, and the women were allotted to their proper Anua [anewe] men' (Spencer \& Gillen 1927, p. 321). Spencer and Gillen (1927, p. 323; 1969a [1899], p. 422) further commented:

It is not without interest to note that, according to tradition, the emu men who introduced the division of the sections now in use live away to the north, because the adoption of the distinctive names for the eight groups thus created is at the present time taking place in the Arunta tribe, and, as a matter of actual fact, these eight names did originate in the north, and gradually spread southwards through the tribe. 
I would add that the meetings described in the final stage may reflect actual memories of the kind of social consultative processes that took place when the Arrernte adopted the eight-term subsection system, around 1880, from their Northern Anmatyerre neighbours.

Another mythological tradition reflects the split of sections into subsections. This story suggests that subsections might at first have been considered by some to be merely alternative names for the pre-existing section names. It also may also indicate that the introduction of subsections did not always result from harmonious consultations. In 1901, Spencer and Gillen recorded from the Warumungu a story about two ant women (so-called because they fed on the eggs of the ant Echilpa):

[The two ant women] quarrelled about their class names. One suggested that they should both be Naralu [Narrurlu, i.e. B1] the other objected and said she intended to be Nungalli [Nangali, i.e. B2] the upshot of the little difference was that they fought until they died. They bled profusely $\ldots$ and the blood may be seen at the present day in the form of some huge red stones at Unbiria where the fight took place. (Gillen 1968, p. 202) ) $^{32}$

The introduction of sections must have complicated traditions about the Dreamings that were associated with particular sacred sites. This may be reflected in stories that attribute two Dreaming persons to a particular sacred site. Spencer and Gillen recorded a tradition concerning the Kaytetye site Anira [Arnerre] in which a euro man Arininga [Areynenge 'euro'] emerged in the Dreamtime:

At sunset he slept, and when the sun arose he split into two, one of whom was a Purula ${ }^{33}$ and the other a Kumara [kemarre] (i.e. father and son). At sunset the two joined together to form a Purula, who went down into the waterhole out of which at sunrise he emerged and divided into two again. After this they remained separate. (Gillen 1968, p. 147; Spencer \& Gillen 1969b [1904], p. 158, cf. p. 418)

This bifurcation was undoubtedly motivated by the fact that this site was linked to the Pwerle and Kemarre patricouple after the introduction of section names (and later subsections). The splitting of the Dreaming would have allowed a pre-existing personage to be equally associated with both of the relevant names.

32 See Spencer and Gillen (1969b [1904], p. 423) for another version of this story.

33 Spencer and Gillen here use the Arrernte form of the skin name in place of the normal Kaytetye Pwerle. 


\section{Possible Implementation of the Subsection System}

We have no direct evidence of how the adoption of the subsections proceeded socially. Nevertheless, some ideas can be proffered on the basis of how this took place elsewhere, as well as from the native traditions. It is likely that not all members of a group adopted subsection names at the same time, but that the adoption of the new system had a certain duration, as argued by Dousset (2005, p. 79) in relation to the adoption of the section system by the Western Desert peoples. The first adopters were presumably people married to members of other groups who already used subsection names. It is possible that group decisions at major get-togethers played a role in promoting the adoption of the system in whole groups, along the lines of Spencer and Gillen's account of the assembly of the Emu people mentioned in the subsection 'Native Traditions on the Origin of Skins'. It is also possible that some members of the group, who perhaps did not participate in such decision-making forums, felt they were being coerced into accepting the new system-as suggested by Strehlow's account of the two Southern Arrernte men (see sub-subsection 'Southern Arrernte'). Spencer and Gillen's mythological account of the two Warumungu women who fought over their subsection names (see subsection 'Native Traditions on the Origin of Skins') may also point to a resistance to the new system of nomenclature. Strehlow's story also indicates the relevance of marriage between four-term and eight-term people (rather than arbitrary splitting of sections) as a factor in promoting the new terms. Gillen's letter (see subsubsection 'Central Arrernte'), in which he stated that 'the blacks about the Mission district ... who mix a great deal with the Chitchica were the first to adopt the system', points to the role of post-contact settlements in facilitating contact, which presumably involved intermarriage, between groups that had formerly used the four- versus eight-term system. It is likely that some confusion obtained for a time after the adoption of the new system. This may partially account for the disparity between Schulze and Spencer and Gillen (see sub-subsection 'Western Arrernte'). Schulze's system involves the simple joining of the original four terms and their filiations with the new set of terms - that is, it continues PenangkePeltharre as a patrifilial pair rather than switching it to Penangke-Pengarte beside Kngwaraye-Peltharre. 


\section{Towards an Absolute Chronology}

On the basis of the formal similarity of Warlpiri terms to those of other languages to their north(west) and evidence for the rapid adoption of similar systems elsewhere, Meggitt (1962, p. 168) concluded that:

The diffusion of subsections in the central desert followed hard on the spread of sections. It is probable that the Walbiri received the section system no more than a century ago [i.e. c. 1860] and subsections 20 or 30 years later [i.e. 1880-1890].

These dates are too recent, as noted by McConvell (1996, p. 131). The subsection system was spreading to Arrernte from the Anmatyerre around 1880. The Anmatyerre and Kaytetye must have had this system somewhat earlier. Kaytetye already had set 2 terms in the early 1870s. The differences in mythology between Kaytetye and Anmatyerre vs Arrernte suggest that the former would have had the subsection system at least a generation earlier than the Arrernte. This would take us back to the first half of the nineteenth century at the latest. There is really no way of knowing how long the Kaytetye and Anmatyerre (or the Warumungu, Warlmanpa and Warlpiri) had the section system before they adopted the subsection system. However, the fact that sets 1 and 2 are treated similarly as loan words indicates that the Arandic languages received the set 1 terms after the major Arandic sound changes had taken place. Unfortunately, we have no way of knowing the date of these sound changes.

\section{Summary and Conclusions}

We have considerably refined the picture of how section and in particular subsections were adopted into the Arandic languages. It has been important not to treat the Arandic languages as a single unit but to distinguish between the various Arandic groups and subgroups-both in terms of the skin names used and the date and direction of their adoption of extra skin names.

We have seen that even separate language groups are not uniform with respect to their skin terms. We have mentioned an Alyawarr subgroup with eight terms instead of the normal four. We have noted a subgroup of the Anmatyerre with Thangale in place of Angale, and observed that some subgroups of the Warumungu used Kappiji in place of Jappaljarri. 
In terms of the direction of spread, the previously accepted northern origin of the terms has been confirmed. However, we have also found that there were two prongs to the southward expansion of the subsection terms: a western wave that took forms from Warlpiri into Anmatyerre and thence into Arrernte, and an eastern wave that involved the transfer from Warumungu and/or Warlmanpa into Kaytetye and thence into Alyawarr.

Our reconstruction of the history of skin names has posited intermediate stages that included forms that are not directly attested $\left({ }^{*}\right.$ marks unattested forms). The main replacements we have posited are 1) Alyawarr has replaced the A term *Apenangke with the A2 Kngwarreye of its neighbours; 2) Kaytetye has replaced a hypothetical D1 form *Apetyarre (preserved in Alyawarr) with Kapetye; 3) in Warlmanpa, the original D1 *Japaljarri became *Japatjarri as a result of sound change, then was later shortened to Japaja; and 4) some of the Warumungu replaced their Jappaljarri with Kappiji, borrowed from Kaytetye, but later abandoned this form in favour of the original Jappaljarri.

We have addressed the issue raised by McConvell regarding the timing of the adoption of skin names relative to the Arandic sound changes of initial deletion. We have claimed that both the original four section terms and the second set of four subsection names were borrowed after the Arandic sound changes affecting the beginning of words, and have explained the absence of initial consonants in the Arandic forms in terms of initial truncation that is characteristic of a pattern of adapting loan words from languages that have preserved their initial consonants. It was only in this sense that 'initial-dropping remained a productive rule in Arandic phonology', as claimed by McConvell (1985, p. 6). We have shown that, in contrast to this adaptation of both the first and second sets of (adult) skin names, the junior skin names of Kaytetye and Anmatyerre followed a more recent pattern of borrowing that does not apply this truncation adaptation.

We have established some dates at which the eight-term system was being adopted and other dates before which the systems must have been adopted. The original set of four section names had spread as far as the southernmost variety, Lower Arrernte, by 1875. The four terms of the second set were already present among the Kaytetye by 1874 . They must have been in Anmatyerre by this time as well, since they were spreading from Anmatyerre into Arrernte during the 1880s. One member of 
the second set was borrowed from either Anmatyerre or Kaytetye into Alyawarr before the eastward expansion to Lake Nash in the 1920s and 1930s. Meanwhile, the junior subsection terms were in Kaytetye by 1901 .

\section{References}

Aboriginal Land Commissioner 1991, Aboriginal Land Rights (Northern Territory) Act 1976, McLaren Creek Land Claim: Report No. 32: Findings, recommendation and report of the Aboriginal Land Commissioner, $\mathrm{Mr}$ Justice Olney to the Minister for Aboriginal Affairs and to the Administrator of the Northern Territory, Canberra: Australian Government Publishing Service.

Breen, G (ed.) 2000, Introductory dictionary of western Arrernte, Alice Springs: IAD Press.

Breen, G 2001, 'The wonders of Arandic phonology', in J Simpson et al. (eds), Forty years on: Ken Hale and Australian languages, Pacific Linguistics 512, Canberra: The Australian National University, pp. 45-69.

Breen, G \& Pensalfini, R 1999, 'Arrernte: a language with no syllable onsets', Linguistic Inquiry, 30, pp. 1-25. doi.org/10.1162/ 002438999553940 .

Dousset, L 2005, Assimilating identities: social networks and the diffusion of sections, Oceania Monographs 57, Sydney: University of Sydney.

Elkin, AP 1939-40, 'Kinship in South Australia', Oceania, 10, pp. 196234. doi.org/10.1002/j.1834-4461.1939.tb00276.x.

Giles, C 1879, 'The "Antakerrinya" tribe, Central Australia', in G Taplin (ed.), The folklore, manner, customs, and languages of the South Australian Aborigines, Adelaide: Government, pp. 89-92.

Gillen, FJ 1896, 'Notes on some manners and customs of the Aborigines of the McDonnell Ranges belonging to the Arunta tribe', in B Spencer (ed.), Report on the work of the horn scientific expedition to Central Australia vol. part IV: anthropology, London: Dulau \& Co., pp. 161-86. 
Gillen, FJ 1968, Gillen's diary: the camp jottings of F. J. Gillen on the Spencer and Gillen expedition across Australia 1901-1902, Adelaide: Libraries Board of South Australia.

Green, J 1998, Kin and country: aspects of the use of kinterms in Arandic languages, MA thesis, University of Melbourne.

Green, J 2010, Central and eastern Anmatyerr to English dictionary, Alice Springs: IAD Press.

Hale, K 1973, 'Deep-surface canonical disparities in relation to analysis and change', in TA Sebeok (ed.), Current trends in linguistics, volume 11: diachronic, areal, and typological linguistics, The Hague: Mouton, pp. 401-58.

Henderson, J \& Dobson, V (comp.) 1994, Eastern and central Arrernte to English dictionary, Alice Springs: IAD Press.

Howitt, AW \& Fison, L 1889, 'Further notes on the Australian class systems', Journal of the Anthropological Institute of Great Britain and Ireland, 18, pp. 31-70. doi.org/10.2307/2842513.

Janda, RD \& Joseph, BD 2003, 'Reconsidering the canons of soundchange: towards a "Big Bang" theory', in BJ Blake \& K Burridge (eds), Historical linguistics 2001: selected papers from the 15th International Conference on Historical Linguistics, Melbourne, 13-17 August 2001, Amsterdam/Philadelphia: John Benjamins, pp. 205-19.

Koch, G (ed.) 1993, Kaytetye country: an Aboriginal history of the Barrow Creek area, Alice Springs: Institute for Aboriginal Development.

Koch, H 1997a, 'Comparative linguistics and Australian prehistory', in P McConvell \& N Evans (eds), Archaeology and linguistics: Aboriginal Australia in global perspective, Melbourne: Oxford University Press, pp. 27-43.

Koch, H 1997b, 'Pama-Nyungan reflexes in the Arandic languages', in D Tryon \& M Walsh (eds), Boundary rider: essays in honour of Geoffrey O'Grady, Pacific Linguistics C-136, Canberra: The Australian National University, pp. 271-302. 
Koch, H 2004, 'The Arandic subgroup of Australian languages', in C Bowern \& H Koch (eds), Australian languages: classification and the comparative method, Current Issues in Linguistic Theory 249, Amsterdam: John Benjamins, pp. 127-50, 575-80. doi.org/10.1075/ cilt.249.10koc.

Koch, H 2007, 'Divergent regularity in word-initial truncation in the Arandic languages', in D Eades, J Lynch \& J Siegel (eds), Language description, history and development: linguistic indulgence in memory of Terry Crowley, Creole Language Library 30, Amsterdam: John Benjamins, pp. 267-80. doi.org/10.1075/cll.30.27koc.

Koch, H 2014, 'Loanwords between the Arandic languages and their western neighbours: principles of identification and phonological adaptation' [available online], in L Gawne \& J Vaughan (eds), Selected papers from the 44th conference of the Australian Linguistic Society, 2013, Melbourne: University of Melbourne, pp. 311-34, viewed 7 August 2017, minerva-access.unimelb.edu.au/handle/11343/40970.

Koch, H \& Simpson, J forthcoming, 'Junior skin names in Central Australia: function and origin', in P Monaghan, M Walsh \& R Lucas (eds), Peter Sutton: Ethnographer and contrarian, Wakefield Press.

Laughren, M 1982, 'Warlpiri kinship structure', in J Heath, F Merlan \& A Rumsey (eds), Languages of kinship in Aboriginal Australia, Oceania Linguistic Monographs 24, Sydney: University of Sydney, pp. 72-85.

Mathews, RH 1899, 'Divisions of north Australian tribes', Proceedings of the American Philosophical Society, 38(159), pp. 75-9.

McConvell, P 1985, 'The origin of subsections in northern Australia', Oceania, 56, pp. 1-33. doi.org/10.1002/j.1834-4461.1985.tb02105.x.

McConvell, P 1996, 'Backtracking to Babel: the chronology of PamaNyungan expansion in Australia', Archaeology in Oceania, 31, pp. 125-44. doi.org/10.1002/j.1834-4453.1996.tb00356.x.

Meggitt, MJ 1962, Desert people: a study of the Walbiri Aborigines of Central Australia, Sydney: Angus \& Robertson.

Mulvaney, J, Morphy, H \& Petch, A (eds) 1997, 'My dear Spencer': the letters of F. J. Gillen to Baldwin Spencer, Melbourne: Hyland House. 
Nash, D 1979, Preliminary vocabulary of the Warlmanpa language, Unpublished manuscript, Cambridge, Mass.: Massachusetts Institute of Technology.

Nash, D 2015, Warlmanpa subsections, accessed 7 August, www.anu.edu. au/linguistics/nash/aust/wpa/kinship.html.

Radcliffe-Brown, AR 1918, 'Notes on the social organization of Australian tribes', Journal of the Royal Anthropological Institute of Great Britain and Ireland, 48, pp. 222-53. doi.org/10.2307/2843422.

Radcliffe-Brown, AR 1930-31, 'The social organization of Australian tribes', Oceania, 1(1), pp. 34-65; 1(4), pp. 444-56.

Schulze, L 1891, 'The Aborigines of the upper and middle Finke River: their habits and customs, with introductory notes on the physical and natural-history feature of the country', Transactions of the Royal Society of South Australia, 14(1), pp. 210-46.

Sharp, JC 2004, Nyangumarta: a language of the Pilbara region of Western Australia, Pacific Linguistics 556, Canberra: The Australian National University.

Simpson, J 2002, A learner's guide to Warumungu, Alice Springs: IAD Press.

Spencer, B \& Gillen, FJ 1927, The Arunta: a study of a Stone Age People, 2 vols, London: Macmillan [Facsimile edition 2011, Virginia, Northern Territory: David M. Welch].

Spencer, B \& Gillen, FJ 1969a [1899], The native tribes of Central Australia, Oosterhout, Netherlands: Anthropological Publications [Reprinted from 1899 edition by Macmillan \& Co].

Spencer, B \& Gillen, FJ 1969b [1904], The northern tribes of Central Australia, Oosterhout, Netherlands: Anthropological Publications [Reprinted from 1904 edition by Macmillan \& Co].

Stirling, EC 1896, 'Part IV-Anthropology', in B Spencer (ed.), Report on the work of the Horn Scientific Expedition to Central Australia, London: Dulau \& Co.; Melbourne: Melville, Mullen and Slade, pp. 1-157. 
Strehlow, C n.d., Aranda-Loritja-English dictionary, Unpublished manuscript, Australian Institute of Aboriginal and Torres Strait Islander Studies, Canberra.

Strehlow, TGH 1947, Aranda traditions, Melbourne University Press [Reprinted 1968, New York: Johnson Reprint Corporation].

Swan, C \& Cousen, M 1993, A learner's wordlist of Pertame, Alice Springs: Institute for Aboriginal Development.

Turpin, M \& Ross, A 2012, Kaytetye to English dictionary, Alice Springs: IAD Press.

Vallee, P 2006, God, guns and government on the Central Australian frontier, Canberra: Restoration.

Wilkins, D 1989, Mparntwe Arrernte: studies in the structure and semantics of grammar, $\mathrm{PhD}$ thesis, The Australian National University.

Yallop, CL 1969, 'The Aljawara and their territory', Oceania, 39(3), pp. 187-97. doi.org/10.1002/j.1834-4461.1969.tb01005.x. 
This text is taken from Skin, Kin and Clan: The dynamics of social categories in Indigenous Australia, edited by Patrick McConvell, Piers Kelly and Sébastien Lacrampe, published 2018 by ANU Press, The Australian National University, Canberra, Australia.

doi.org/10.22459/SKC.04.2018.10 